\title{
URCI Y SAN INDALECIO
}

Por

JOSE GARCIA ANTON 
Vamos a abordar un tema difícil en todo su desarrollo, ya que está cargado de intereses localistas, por un lado, en cuanto a la situación de Urci (1), y de carácter polémico, por otro, en cuanto el hablar de esta diócesis comporta el tratar de su primer obispo, San Indalecio, y por tanto de los Siete Varones Apostólicos, cuya realidad está hoy puesta en duda (2). Intentaremos a lo largo de este trabajo seguir una actitud puramente de investigación, clentro de un historicismo científico, para tratar de obtener las consecuencias que de los hechos históricos se deduzcan.

Estas consideraciones previas nos conducen al establecimiento de una hipótesis acerca de Urci, y a los problemas que su estudio lleva consigo. No hacemos una afirmación de la verdad histórica, sino tan sólo un intento de aproximación a ella. Las polémicas que se puedan suscitar cuentan con un total respeto, ya que pueden llevarnos a una correcta interpretación del "hecho Urci".

(1) Efectivamente dentro de la historiografía actual una gran mayoría de los investigadores o historiadores, al tratar sobre Urci, de pasada, la sitúan en Pechina (Almería); así Leví Proven. çal, Garcia Bellido, Torres Balbas, J. Vives, etc. Otros la llevan a Villaricos, como Garcia Villada. M. Torres, Cánovas Cobeño.

(2) Cierto número de historiadores contemporáneos manifiestan claramente sus dudas sobre la veracidad de la tradición de los Varones Apostólicos, entre ellos, Blázquez, Vives, Tarradell Mateu. 
En el desarrollo de este trabajo haremos primero una exposición de los antecedentes de Urci, tratando brevemente de su época ibérica y romana, de las noticias que sobre ella tenemos, sin entrar en su discusión, ni por tanto en los problemas que su ubicación comporta. Hablaremos después de ?a sede urcitana y de su fundador San Indalecio y por tanto del aspecto histórico de los Siete Varones Apostólicos, tratando de obtener las consecuencias que se deriven de estos estudios.

\section{URCI EN LAS FUENTES}

Veamos cuáles son los antecedentes que nos llevan a la primera consideración de la existencia de una ciudad llamada Urci.

Ciñéndonos a las fuentes, las primeras noticias se sitúan en Pomponio Mela (s. I), quien dice que se encuentra "al fondo del golfo llamado Urcitanus" (3). Por estas mismas fechas, Plinio también la menciona, indicando que "en la costa se hallan los oppida de Urci y Baria, adscrito este último a la Bética; la región de la Bastitania, luego de la Contestania y Carthago Nova" (4). De donde deducimos que Urci es ciudad costera que se encuentra en el fondo del golfo a que da nombre y al mismo borde del mar (5). Tolomeo afirma: "Post Baetica terminum qui erat 12-37'15. Bastitanorum littoralis ora Urci $12-37^{\prime} 20$. Contestanorum littoralis ora Lucentum 12'10-37'30. Carthago Nova 12'15-37'55" (6). Lo que nos confirma: primero, que Urci es el puerto de los bastetanos; segundo que se encuentra entre el límite de la Bética y de la Contestania, de la que menciona los puertos de Lucentum - ta! vez Mazarrón- y Cartagena.

El anónimo datado, para unos, en los finales del s. III y para otros, en los tiempos del Concilio de Elvira, principios del s. IV, conocido como

(3) GARCIA BELLIDO.-La España del s. I de unestra era (según Pomponio Mela y C. Plinio). Ed. Espasa Calpe (Col. Austral). Buenos Aires, 1947. p. 31.

(4) Ibídem. p. 130.

(5) Plinio al hablar de Valentia y Saguntum precisa se encontraban a 3.000 pasos del nar.-GARCIA BELLIDO. p. 130 y p. 232 (nota 91).

(6) FLOREZ.-España Sagrada. Madrid, 1779. T. V, p. 394. 
"Itinerario de Antonino", menciona una ruta que partiendo del interior en Cástulo (Cazlona), alcanza la costa en Urci, y por ella sigue hasta Málaca (Málaga). Así de Acci (Guadix) pasa a Alba (Abla), de aquí a Urci, y luego a Turaniana y Murgis (7). Este itinerario ofrece varias interpretaciones, ya que algunos de los lugares son de identificación discutible. Por ello, intentar la localización de Urci basándose en él, puede dar lugar a errores notables. Como ya se ha señalado, contemporáneo de la redacción del anterior itinerario son las actas del Concilio de Elvira. En ellas figura entre los obispos que las firman Cantonio de Urci y su presbítero Jenaro (8). Lo anterior añade dos precisiones más sobre Urci. Una es que se encontraba en un itinerario importante dentro de las vías romanas. Otra que en el s. IV tiene categoría de sede episcopal.

En época visigoda, Urci figura en varias de las actas de los concilios toledanos (9); ya en tiempos del islam, en una relación de sedes episcopales (10), y en el concilio celebrado en Córdoba, en el s. IX, para juzgar al Abad Samson (11).

Cuando se extiende la tradición de los Varones Apostólicos, Urci figura como una de las sedes de éstos, la de San Indalecio, que aparece como fundador de ella. Esta tradición es detenidamente estudiada por Vives, y sus primeras noticias parece se remontan a unas actas del s. VIII (12). Tres siglos después, en ocasión del traslado de las reliquias de San Indalecio desde Pechina a San Juan de la Peña (1084) Urci vuelve a ser mencionada (13).

(7) ROLDAN HERVAS, J. M.-Itineraria bispana. Madrid, 1975. pp. 55-56.

(8) VIVES, J.-Concilios Visigóticos. Madrid, 1963. p. 1.

(9) Ibídem.-En las relaciones de los obispos que firman las actas figura en los once concilios de Toledo que siguen: IV (p. 223), V (p. 230), VIII (p. 288), IX (p. 307), X (p. 319), XI (p. 368), XII (p. 401), XIII (p. 432), XIV (p. 447), XV (p. 473), y XVI (p. 519).

(10) GARCIA VILLADA, Z.-Paleografía española.-Barcelona, 1974. T. I. Texto p. 154. El autor hace la transcripción del Fol. 65 v. del manuscrito R. II. 18 de El Escorial titulado "Nomina civitatum ispania sedes episcopalium" que comprende una lista de sedes episcopales fechadas por los años 778-79.

(11) FLOREZ.-España Sagrada. T. XI, p. 311.

(12) VIVES, J.- Artículo Varones Apostólicos en Diccionario de Historia Eclesiástica de España. (Instituto Enrique Flórez. C.S.I.C.), Madrid, 1975. T. IV, p. 2.715.

(13) Crónica de San Juan de la Peña.-Versión latina preparada por A. UBIETO ARTETA. Valencia, 1961. p. 56. 
Don Lucas de Tuy (El Tudense) al tratar, en 1204, "De la equiuacion de los nonbres de las cibdades villas y castillos de España" (14), al hablar de la Hitación de Wamba, sitúa a Vrgi en Almería, lo que suponemos debió ser motivado a su conocimiento de la Crónica de San Juan de la Peña. También Alfonso X, en 1270, en su General Estoria, basándose en el Tudense escribe: "el obispado de Vrgi esta es Almeria” (15).

En los siglos XVI y XVII proliferan las menciones de Urci situándola la mayoría de los escritores en Almería, llevándola otros a Vera al interpretar las citas de Mela y Tolomeo.

Eruditos e historiadores del s. XIX se ocupan de una forma precisa en intentar localizar el solar de Urci. La mayoría lo sitúan en Pechina cerca de Almería, y esta opinión prevalece en el siglo actual entre los historiadores que, de pasada, tratan de Urci o de la Bayyana árabe.

La aparición en el siglo pasado de una serie de monedas ibéricals acuñadas por la ceca URKEKEN, identificada con Urci, retrotrae la existencia del citado poblamiento en varios siglos. Gómez Moreno afirma: "que las últimas emisiones de ases fueron copiadas a nombre de URCESCEN" (16). Para Mateu Llopis (17) el estilo de esas piezas corresponden a una población marítima ibérica. Caro Baroja (18) publica una moneda de ceca URCESCEN la que identifica con la Urci de Tolomeo. Por último en el Plomo de Alcoy también aparece la palabra URKE (19). De lo anterior se deduce la existencia de un asentamiento ibérico en la costa oriental de

(14) TUDENSE.-Crónica de España for Lucas obispo de Tuy (Cbronicon Mundi).Editada por J. PUYOL. Madrid, 1926. p. 222.

(15) ALFONSO EL SABIO.-Primera Crónica General de España. Publicada por MENEN. DEZ PIDAL. Madrid, 1955 (1. ${ }^{n}$ Ed. de 1906). T. I, p. 296.

(16) GOMEZ MORENO, M.-Notas sobre numismática bispana. En Crónica del IV Con. greso arqueológico del Sudeste español. Elche, 1948. p. 231.

(17) MATEU LLOPIS, F.-Las cecas ibéricas bastesanas, en Crónica del IV Congreso arqueo. lógico del Sudeste español. Elche, 1948, p. 231.

(18) CARO BAROJA, J.-La escritura en la España presromana. (Epigrafía y Numismáiica). En Historia de España dirigida for MENENDEZ PIDAL. T. 1/3. p. 735. Madrid, 1954.

(19) Ibidem. p. 795. 
la Península, conocido por Urce o Urke, que podría identificarse con la Urci que estudiamos.

Así, pues, con todas las noticias extraídas de las fuentes señaladas, podrá determinarse la evolución de Urci. Primero aparece por las cecas de las monedas como un establecimiento ibérico. Pasa luego a ser un oppida hispano-romano, en el que es establecida una diócesis, de datación segura en el s. IV y que tras una laguna de dos siglos, vuelve a figurar en el s. VII, en tiempos visigodos, continuando figurando en época islámica en los siglos VIII y IX. A partir del s. X desaparece, dejándonos la incógnita de cuál fue su verdadero asentamiento, lo que ya sólo la arqueología podrá resolver.

Mucho se ha escrito sobre Urci. ¿Cómo una pequeña aldea, mal llamada ciudad, que llegó a ser sede episcopal, ha sido objeto de tantas referencias, comentarios y aun discusiones? La respuesta creemos está en dos motivaciones. La primera, haber sido la sede de San Indalecio, cuyas reliquias, tras ser llevadas a San Juan de la Peña, hoy reciben culto en Jaca. La segunda, es que al aparecer las citadas reliquias en Pechina, y al ser ésta la antecesora de Almería, es motivo de darle a esta ciudad una patente de nobleza, al hacerla proceder de la Urci ibérica y romana, cuya sede espiscopal, de las más antiguas de España, se remonta a los tiempos de la primera cristianización de la Península, recibiendo el patronazgo de un santo discípulo de los Apóstoles.

Creo que, los anteriores, son sobrados motivos para despertar un interés local por Urci, que luego tomará un carácter histórico en el contexto nacional, al precisar la comprobación de la temprana evangelización de la Hispania, de la que son prueba fehaciente las reliquias del santo fundador de la diócesis urcitana.

\section{SAN INDALECIO OBISPO DE URCI}

Si nos atenemos a lo que dicen los historiadores del s. XVIII, la sede urcitana es fundada en el s. I de nuestra era por San Indalecio que es con- 
siderado su primer obispo, del cual el Padre Florez dice: “Este después de haber estado con los demás en Acci, y haver visto los prodigios que obró Dios por su medio, escogió para theatro de su apostólico empleo, la ciudad de que tratamos, siendo su primer Predicador y Obispo, por cuyo medio empezó la cristiandad en Urci". (20).

Más adelante el mismo autor señala que de San Indalecio "sólo sabemos lo que el Oficio Gothico refiere en el Oficio de los Siete Apostólicos" (21), aparte de su entrada en España en compañía de los otros seis Varones, y de los cuales más adelante trataremos. Por último añade Florez "que dejó rubricada con su sangre la fé que predicó" (22). Con lo cual quiere indicar que murió mártir. Sin embargo, la liturgia mozárabe al referirse a los Varones Apostólicos, los llamó "Doctores de la Fé", y la mayor parte de las fuentes sólo dicen "descansaron en paz" (23). Esto hace pensar que no está clara su condición de mártires. Según J. Vives, del estudio de varios códices se desprende que los "Varones Apostólicos fueron confesores en la acepción moderna de la palabra, no mártires" (24), y que por tanto murieron de muerte natural.

A San Indalecio, Tapia (25), al tratar de los Obispos de Almería, le considera el primero, fundador de la sede urcitana, siendo ésta la antecesora de Almería.

(20) FLOREZ. T. VIII. p. 219.

(21) Ibídem, Pp. 219-20.

(22) Ibídem. p. 220.

(23) GARCIÁ VILLADA, Z. (Historia eclesiástica de España. Madrid, 1929, p. 167), al examinar los documentos que hacen referencia a los Siete Varones Apostólicos se encuentra que sólo en dos de ellos (los Calendarios E. y F. -así nombrados por Ferotín- que se corresponden a un códice de París, escrito en Silos en 1067 y a orro igualmente de Silos de 1072 " conservado también en París) reciben el título de mártires. Los otros cinco vistos, sólo dicen "descansaron en paz". Por ello, este historiador deja la incógnita de si fueron mártires o no, sin inclinarse a la opinión de Gams que, en oposición al P. Flórez, afirma que no puede considerárseles como mártires.

También LIORCA.- Edad Antigua. T. 1. de Historia de la Iglesia (B.A.C.), Madrid, 1950. p. 142.

(24) VIVES, J.- Tradicion y leyenda en la bagiografia bispana. En Hispania Sacra. Vol. XVIII, Madrid, 1965. p. 500.

(25) TAPIA GARRIDO, J. A.-Los Obispos de Almería. Almería, 1968. p. 6. 
El segundo obispo conocido de la diócesis de Urci es Santiago, al que se considera sucesor de San Indalecio. Según el Padre Flórez su "nombre y honor espiscopal consta en la Historia de San Juan de la Peña, según refiere Briz en p. 579 y en Zurita sobre el año 1084 de sus índices latinos" (26).

Tapia, basándose en el autor anterior le da "como discípulo y sucesor de San Indalecio" (27). Supone con Flórez que Zurita pudo haber visto algún otro documento aparte de la relación de Ebretmo. En los Anales Toledanos figura "Mudaron el cuerpo de S. Indalecio de la cibdad que avia de nombre Urcitana, et la cabeza de Santiago, Bispo a San Juan de la Peña en el Monesterio" (28).

Ahora bien, el mismo Padre Flórez nos da unas ciertas aclaraciones sobre el supuesto Santiago: Dice que la primera noticia de su nombre figura en una nota marginal del relato de Ebretmo "Santiago Obispo de Urci" (29), en la parte en que cuenta el sueño en que se le aparece un venerable anciano al monje Evancio (30).

La segunda noticia la da al manifestar que "según el texto dado de los Anales Toledanos, fué también trasladada a San Juan de la Peña la cabeza de Santiago Obispo de quien no tenemos más mención que la de este documento y la noticia marginal de la Historia de Ebretmo" (31).

Así pues, como vemos, es bien poco y difuso lo que hay respecto a Santiago obispo, sucesor de San Indalecio. En la supuesta fuente más antigua, Ebretmo (s. XII), aparece sólo en una nota marginal y no en el texto, lo que puede ser un añadido posterior. En la otra, los Anales Toledanos (s. XVI), más explícita, nos habla del traslado de la cabeza de Santiago

(26) FLOREZ. T. VIII, p. 220.

(27) TAPIA. p. 6.

(28) Anales Toledanos.-Ed. Berganza. p. 568.

(29) FLOREZ. T. VIII. p. 220.

(30) Ibídem. p. 227.

(31) Ibidem.p. 230. 
en unión de las reliquias de San Indalecio a San Juan de la Peña. El propio Padre Flórez supone que Zurita debió ver algún otro documento desconocido, lo que para nosotros es mucho suponer. Todo ello, lleva a tener grandes dudas sobre la misma existencia de este obispo urcitano, ya que incluso la misma fuente esencial, Ebretmo, como más adelante veremos, es dudosa en cuanto a los hechos en ella relatados.

Para terminar. Si como los Anales Toledanos dicen la cabeza de Santiago fue trasladada con las reliquias de San Indalecio, ¿Qué se hizo de ésta? ¿Por qué se trasladó sólo la cabeza y no todos sus huesos? Y por último, ¿Cómo es que Ebretmo nada nos dice del hallazgo de los huesos de Santiago? Todo como vemos cae más dentro de la leyenda que de la realidad histórica.

Pasemos otra vez a tratar clel primer obispo urcitano, San Indalecio. Sobre él se presenta un problema que como historiador no podemos soslayar. Es el concerniente a su misma identidad.

Hay un hecho fehaciente, es la existencia de sus reliquias que reciben culto en la Catedral de Jaca, donde se conservan en una urna de plata en su altar mayor. Hay también unas relaciones históricas del traslaclo de esas reliquias desde Pechina y su llegada a San Juan de la Peña.

Examinemos las fuentes que a ello se refieren. En primer lugar, está la relación de Ebretmo, en la que tras indicar que fueron descubiertas en Paschana (Pechina) las mencionadas reliquias, nos relata su traslado a San Juan de la Peña y de cómo fueron recibidas en el Monasterio por el Abad y su comunidad, así como por el "Rey Don Sancho que con su hijo Don Pedro se hallaba allí observando la Queresma" (32). Este traslado también figura en la Crónica de San Juan de la Peña, escrita entre los

(32) Ibidem. p. 228. Dentro de esta misma relación de Ebretmo, se precisa que "esta traslación fue en 1084 en la Era de 1122 dia 28 de Marzo (quinto Kal. Aprilis)" concluyendo "asportatos est in Ecclesiam B. Joanis Baptistae, qui de Penna Dicitor, me vicente, Hebrethmo scilcet, indigno cluniacensis Coenobii Monacho (qui hanc translationis paginam jussu praelibati Abbatis dictavi ut valvi) ann ab Incarnatione Domini MLXXXIV. Era sciliet MCXXII quin. Kal. Aprilis". 
años 1369-1372 (33). Igualmente Zurita se refiere a este traslado (34), y este mismo autor al tratar de la entrada por mar que hizo en Almería, en 1309, Jaime II vuelve a mencionar las reliquias de San Indalecio (35).

Todo lo anterior nos lleva a la certidumbre del traslado de estas reliquias desde Pechina, cosa que corrobora la presencia de las mismas en la actualidad en Jaca.

Ahora bien, hasta aquí el hecho histórico. Los antecedentes del mismo, vistos bajo un concepto científico de la historia, hemos de considerar, como a continuación vamos a ver, caen más dentro de la leyenda que de de la realidad histórica.

Comencemos haciendo un análisis exhaustivo de la propia relación del monje Ebretmo, de la cual el Padre Flórez en el "Capítulo último" del "Tratado XXVII De la Iglesia Urcitana", en sus números 36 a 39 nos da una completa descripción (36). A través de él, intentaremos separar, aque-

(33) "Anno $\mathrm{M}^{\circ} \mathrm{LXXX}{ }^{\circ}$ quarto et corpora Sancti Indilexi et Sancti Iacobi eius discipuli qui post ipsum fuit episcopus ciuitatis d'Utic qui nunc uocata est Almaria, fuerunt tranlata honorifice fro reliquiis ad monasterium Santi lohanis de la Penya per dictum regem Sanctium Remiri et eius filium Petrum et per Sanctium abbatem dicti monasterii, sancta die lovis Cene, nonas aprilis, feria quinta".-Crónica de San Juan de la Peña. Versión latina e índices preparados por Antonio UBIETO ARTETA. Valencia, 1961. pp. 56.5\%.

(34) " $Y$ en el mismo tiempo, refieren que fue lleuado al Monasterio de S. Iuan de la Peña, el cuerpo de Sāto $\bar{d}$ Indalecio d la ciudad de Almería, que esta no lex de aquella ciudad, que antiguamente dixeron Vrci, Lugar muy celebrado en España Citerior, en los mismos confines de la Bética, en la costa de los pueblos que dixeron Bastetanos, y fue con grande solenidad recebido el Jueues santo de la Cena, por el Abad del mismo Monasterio llamado Sancio, hallándose presente el Rey Don Sancho y el Infante Don Pedro su hijo." ZURITA, G. Anales de la Corona de Aragón. Zaragoza, 1669. T. I. Fol. 28, Col. 2r. y 3v.

(35) Este rey "Procuró antes con el Abad de San Juan de la Peña que le diese un brazo - alguna reliquia del cuerfo de Sant Indalecio, obispo que fue en la primitiva ciudad de Urci, de cuyas ruinas se fundó Almería, así por la devoción que tenia en aquel glorioso santo que fue discipulo de Santiago cuya memoria y santidad era muy reverenciado en este reino, como por haberle tomado por su patrón en aquella expedición". ZURITA. Anales de Aragón. Ed. CA. NELLES LOPEZ, A. Zaragoza, 1970. p. 714.

(36) FLOREZ. T. VIII. pp. 226-28, da completo el relato del Monje Ebretmo.

Sobre esta relación y su autor debemos hacer constar la opinión de TAPIA GARRIDO ( $A$ l. meria Musulmana. Almería, 1976. p. 296) quien afirma que, el Monje Ebretmo que redacta el Acta del Traslado de las reliquias de San Indalecio, es un falsario que escribe en época muy posterior a los hechos, aun cuando es opinión del mismo Tapia, no se debe rechazar "sin más 
lla parte que puede caer dentro de un contexto histórico, de aquella otra que podemos considerar como pura leyenda.

Se inicia, según Flórez, el relato de Ebretmo, hablando de "los deseos que el Abad Don Sancho tenía de ilustrar su casa con reliquias a cuyo culto era muy inclinado" (37). Caen completamente estos "deseos" dentro de los criterios generalizados en el s. XI, en el que proliferan el culto a las reliquias en iglesias y monasterios, especialmente en estos últimos.

Dice después, que el dicho abad "sabiendo las de San Indalecio se encontraban junto a Almería en tierra dominada de moros" (38), lo cual viene a indicar cómo Don Sancho conocía la tradición de los Varones Apostólicos y de cómo tenía noticias de la existencia de las reliquias de un santo de nombre Indalecio, bien en una supuesta Urci, próxima a $\mathrm{Al}$ mería, o bien, de cómo habían ido a parar a la Bayyana islámica, cosa que no es de extrañar, pues sabemos cómo en la época del florecimiento de esta ciudad, los grupos mozárabes eran muy numerosos en la que fue República de marineros, tasta tal punto, que una de las puertas de la madina estaba presidida por una imagen de la Virgen (39). Esto nos lleva a suponer que en una iglesia o ermita de Bayyana hubiese un culto de estas reliquias y que el conocimiento del mismo, llegase al abad de San Juan de la Peña, dado que, según se infiere de lo que más adelante veremos, el tránsito de los peregrinos a Santiago, procedentes del sudeste y levante pasaba por este monasterio para alcanzar la ruta jacobea.

Aparece a continuación, en relato, la figura de Don García, noble castellano al servicio del Islam en Murcia, y cuya figura Bohajar ha estudiado

su narración pues demuestra conocer el ambiente y circunstancias dominantes en el Sudeste durante la segunda mitad del s. XI y de los datos esenciales del suceso" a que se refieren los Anales Primeros Toledanos y los de Zurita, suponiendo pudo tener a mano un documento orivinal de San Juan de la Peña, perdido después, al que adornaría "con sucesos sobrenaturales tan característicos de la hagiografía medieval".

(37) Ibídem. p. 226.

(38) Ibídem. p. 226.

(39) LEVI PROVENÇAL.-La Peninsule lerique au Moyen Age d'aprés Ar-Raud al.




detenidamente (40). Este caballero, pariente del abad "vino a San Juan de la Peña con ocasión de pasar a Santiago de Galicia" (41). Esto nos confirma lo que antes hemos dicho, como la ruta de peregrinación desde levante y Murcia pasaba por San Juan de la Peña para alcanzar Galicia. $\mathrm{Y}$ también que, debió ser frecuente, entre los mozárabes, el peregrinar a Santiago. El abad manifiesta al caballero "su pretensión" de conseguir estas reliquias, a lo cual Don García ofrece su cooperación, y a su regreso dos monjes del monasterio le acompañan, Evancio y García, con el fin de conseguir las preciadas reliquias.

Don García, debió juzgar factible el conseguir éstas, pues por esas fechas, finales del s. XI, Bayyana se está convirtiendo en un despoblado, absorbidos sus habitantes por la populosa y creciente Almería (42). También por el proceso creciente de islamización de todas estas tierras, las comunidades mozárabes deben estar en plena decadencia, siendo muy posible que iglesias y ermitas vayan siendo abandonadas.

Hasta aquí, pues, no hay inconveniente en admitir la consideración histórica de los hechos, en cambio la parte que vamos a tratar a continuación, como podremos ver, empieza ya a caer dentro de la leyenda, no resistiendo un análisis científico de los acontecimientos.

Cabe la posibilidad que Don García se trasladase con su hueste a Pechina, tomándola como base para atacar Almería (43) y que aprovechase

(40) BOHAJAR AGULLO, J.-Murcia en la traslación de San Indalecio. Murgetana XXXII, Murcia, 1970.

(41) FLOREZ. p. 226. T. VIII.

(42) EDRISI.-Description de l'Afrique et de l'Espagne. texte et traduction de DOZY et DE GOEJE.-Leiden 1968. p. 245 trad.

(43) Según aparece en la relación de Ebretmo que nos transmite el P. FLOREZ (España Sagradia T. VIII.) "el Rey Moro de Sevilla tenia guerra con el de Almeria; y llamando este en su ayuda al Cavallero D. Garcia (del cual sabemos era "residente en Murcia) llegó este... a Paschana (Pechina) para dar contra Almería" (p. 226). Más adelante nos dice cómo los monjes que acompañan a D. García piden la intercesión de San Indalecio "a fin que no pereciesen tantas vidas de Christianos que luchaban empleados en uno y otro Egercito" y cuando ya estaban "esquadronados los campos salió orden del Rey de Sevilla para que se retirase su tropa" (p. 228), considerándose este como el primer milagro del santo. 
esta expedición para llevar los monjes a este lugar. No debió ser difícil a éstos, localizar el templo o ermita, en la cual recibían culto o estaban enterradas las reliquias del santo. Pero ahora bien, en la relación se dice que los monjes "frecuentaban el templo donde estaban las reliquias del santo pidiendo a Dios con ayunos y oraciones les mostrase algún indicio del sitio donde yacía el cuerpo”. Ante esto, debemos preguntarnos, ¿Cómo sabían los monjes que en ese "templo" precisamente, estaban enterradas las reliquias del santo, si ni tan siquiera se conocía el lugar donde estaban? Ello no podía ser, en tal caso, sino debido a alguna tradición que algún mozárabe conocía y que les llevó hasta allí.

Este "templo", nosotros suponemos pudiera tratarse de un antiguo martyrium hispano-romano, en el que se veneraban las reliquias de un mártir de la comarca que, en tiempos anteriores al Islam y aun bien entrado éste, fue objeto de veneración por los mozárabes del lugar. Mártir de nombre Indalecio, cuya fama trascendió por los reinos de Almería y Murcia. El martyrium pudo muy bien encontrarse en las inmediaciones de una villa. Sabemos que cuando llegan a establecerse los marinos Bayyana no es más que un conjunto de barrios dispersos (44) y tal vez uno de ellos tuviera su antecedente en una antigua villa a cuya inmediación se encontraba el martyrium. Pero hasta aquí sólo son suposiciones que dejamos apuntadas, y a las que más adelante volveremos. Antes deberemos dejar constancia de que el nombre Indalecio parece de es-

De lo anterior debemos suponer la existencia en 1084 de una expedición de Almotamid de Sevilla, que fosee Lorca y su distrito, contra Almotasin de Almería, para lo cual solicita la ayuda de la hueste de Don García que estaría al servicio de Ibn Raxic de Murcia, pero guardando, tal vez, una cierta dependencia de Almotamid. Pues, que el noble castellano reside en Murcia, se comprueba al seguir el texto, ya que más adelante nos dice cómo se retira a esta ciudad e incluso cómo los monjes se detienen en ella más de la cuenta.

Debe hacerse notar, además, cómo también el régulo de Almería tiene, al igual que el de Sevilla, una hueste cristiana, lo que puede hacernos suponer que antes de la llegada de los almorávides, la principal fuerza militar de los reyes taifas residiese en mercenarios cristianos. Esto pudo suponer ser causa de la debilidad del islam ante los reinos del norte, ya que cabe la posibilidad de la existencia de una cláusula por la cual estas huestes no se comprometian a combatir a sus hermanos de religión, o bien la existencia de una cierta desconfianza en su empleo contra los reinos cristianos for los musulmanes. Esta sería una explicación más de la solicitud de ayuda a Yusuf, pese al riesgo que esto comportaba.

(44) LEVI PROVENÇAL.-p. 47 trad. 
tirpe ibérica, precisamente el único de entre los Siete Varones, pues los otros seis son romanos (45). Para finalizar concretaremos, la posible existencia de un santo mártir ibérico de nombre Indalecio, igual que el del Varón Apostólico Obispo de Urci.

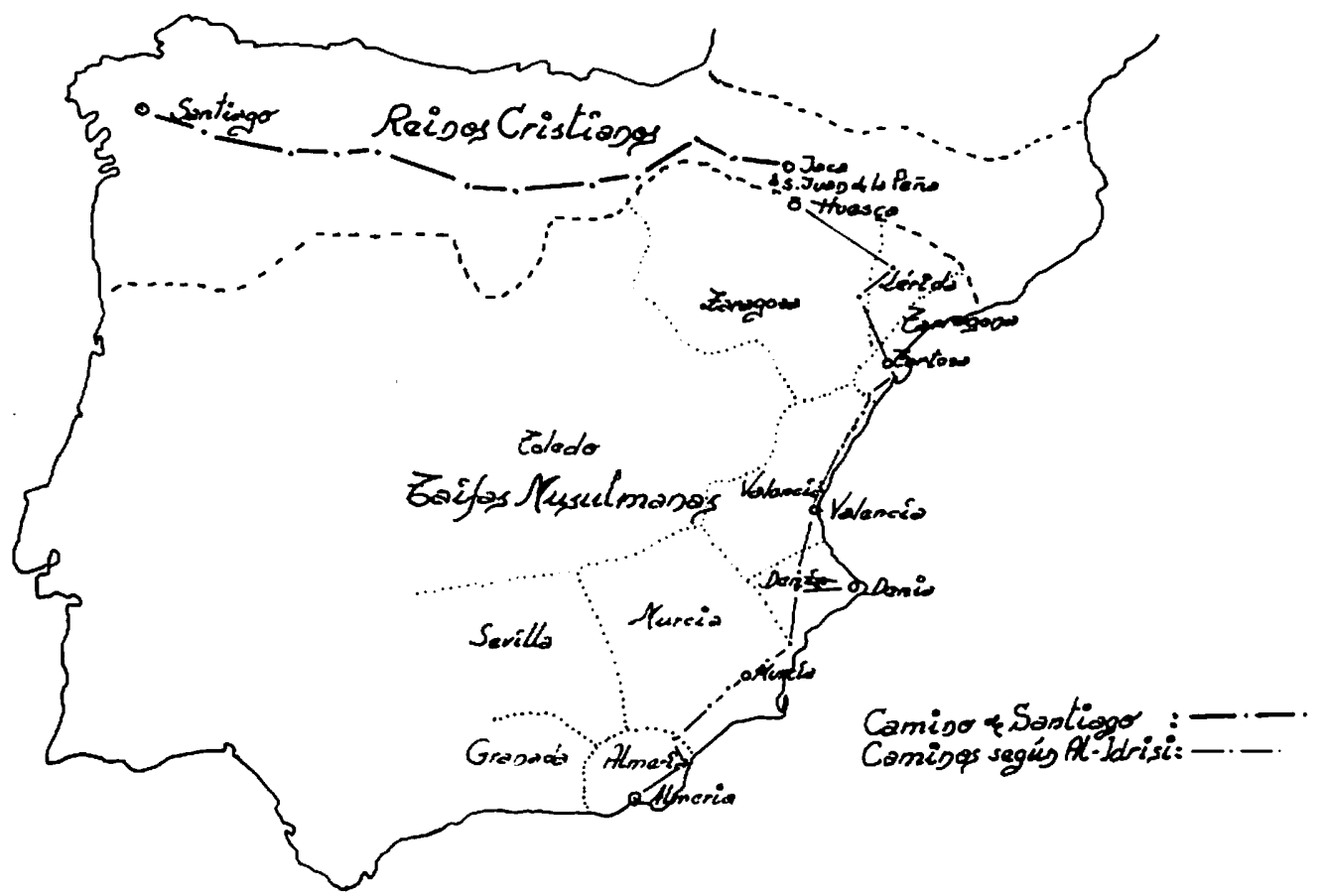

Posible itinerario de los mozárabes del Sureste peninsular en las peregrinaciones jacobeas. Este es el que debió seguir el Caballero Don García (jefe de la hueste cristiana en Murcia) de la relación de Ebretmo, según se desprende de los lugares por los que, el mismo relato dice, pasaron las reliquias de San ndalecio en su traslado a San Juan de la Peña.

Mapa confeccionado con los datos de UBIETO ARTETA (Atlas histórico.Cómo se formó España) según sus mapas: 59, Los reinos de Taifas; 72, Los caminos. Según Al-Idrisi ; 94, El Camino de Santiago.

(45) GARCIA VILLADA, Z.-Historia Eclesiástica de España. Madrid, 1929.-T. I. 1.a parte. p. 159. 
Siguiendo la relación de Ebretmo, vemos cómo "se le apareció a Evancio un gallardo Joven que preguntándole lo que buscaba en aquel templo y oyendo que las reliquias de San Indalecio, le declaró el Angel, que hallaría su sepultura en la parte que le señalaba con la mano, donde se levantaba de la tierra una llama". En este mismo sueño también se habla de "un viejo venerable, adornado de vestiduras preciosas, que preguntado por el Monge quien era, respondió que hasta entonces havia sido custodio de aquel templo de San Indalecio su señor: pero que ya pues el mismo Santo quería irse con los Monges, también él le acompañaría" (46).

Si al primer párrafo le despojamos de la parte legendaria, en el "gallardo joven" podremos ver sólo a un mozárabe del país, que simplemente le indica con la mano el lugar en que, según ellos conocen, está sepultado el santo, y no precisamente a través de un sueño. Este hecho simple, siguiendo el gusto de la época, debió ser transformado, con el fin de dar más carácter al santo, en un acto milagroso que indicara dónde estaban las reliquias.

Pero es que, en este mismo sueño, en su segunda parte, como hemos visto, aparece también el viejo venerable "custodio" del templo, el que posiblemente después sería identificado con Santiago, el segundo obispo urcitano, del que antes hemos tratado. Es muy posible su verdadera existencia. Se trataría, en tal caso, de un anciano sacerdote mozárabe, precisamente custodio del famoso templo y de existencia real, pero que ha convenido introducirlo en el relato del sueño.

En esta segunda parte aparece una afirmación que no tiene conexión con el relato, y es la que el santo quiere irse con los monjes. El autor nos quiere llevar a este convencimiento, ya que para él, el solo hecho de que el joven indique el lugar en que se encuentran las reliquias, quiere decir que el santo quiere abandonar las tierras de Almería para trasladarse a San Juan de la Peña, cosa que más adelante, se volverá a hacer patente, con ocasión de detenerse los monjes más de la cuenta en Murcia.

(46) FLOREZ. p. 227. 
Así, pues, todo lo anterior nos lleva a considerar esta parte del relato como una pura leyenda, basada en unos hechos, tal vez, reales.

Si pasamos al hallazgo del sepulcro y de cómo se consiguen las reliquias, veremos que la relación continúa dentro de la leyenda, tras el detenido análisis de los hechos narrados.

Primero nos habla de las dificultades, pues hay que "proceder con cautela" (47). Esto nos indica que la intención es llevarse las reliquias en contra de la voluntad de los habitantes del lugar, los que por tanto conocían su existencia y debían saber dónde estaban enterradas. Suenan las cajas y el ejército debe salir hacia Almería, lo que "facilita el intento de los Monges que así quedaron más seguros" (48). No es comprensible este párrafo, pues si Don García era su protector, no se entiende que con su marcha los monjes estén más seguros. Más tarde, suponemos que el toque de caja hace que los habitantes del lugar huyan ante la proximidad del combate, con lo cual no habrá gentes que les impidan sus propósitos.

Penetran en el templo ambos monjes, acompañados de un capellán de Don García y dos soldados, los que quedan custodiando la puerta. El que tenga que haber una vigilancia indica que hay necesidad de una protección de la acción que se va a llevar a cabo, la que no va a ser necesaria, ni por la presencia del ejército, ni de los musulmanes, que nada tienen que ver con un culto católico, sino precisamente por la de los mozárabes que sí tienen veneración por estas reliquias.

Dice a continuación que "estuvieron cabando hasta la noche". Si el sitio le había sido señalado, no entendemos cómo necesitaron todo un día para hacer la excavación. "Pero hallando allí mismo unos cirios pudieron proseguir" (49), la existencia de los cuales demuestra la de un culto en templo. Gracias a ellos, pudieron leer en la parte interior de la urna:

(47) Ibídem. p. 227.

(48) Ibídem. p. 227.

(49) Ibídem. p. 227. 
"Hic requiescit Indaletius, primus Pontifex Urcitanae Civitatis ordinatus a Sancti Apostolis Romae" (50). Estimamos fue preciso se hiciese de noche para, gracias a unos cirios, leer la inscripción. Con ello se tranquilizaba la conciencia del autor del relato, puesto que al haberse leído la inscripción con una débil iluminación, pudieron cometerse errores. El párrafo añade que al levantar "la piedra y salió tanta fragancia del sepulcro" (51). Por tanto indica la existencia de un doble sepulcro, primero la urna con su inscripción y luego la piedra que cubre el cuerpo. Tal vez esto confirme hallarnos ante una capilla martyrial, en que sobre la tumba del santo se ha levantado un pequeño altar, la urna de que habla el texto, esto le daría una cierta claridad.

Con todo, nuestra opinión es que en ningún momento hubo inscripción, o si la hubo no fue la que aparece en el relato. Su fin es sólo el colofón de cuanto antes se viene diciendo. Ella corrobora que los monjes se encuentran ante los restos del obispo urcitano. Por lo que cabe a la fragancia que se desprende al abrir el sepulcro, cae dentro de los relatos medievales que hacen referencias a tumbas de santos.

Pasamos a la última parte del relato, en ella dice cómo "no pudiendo proseguir la maniobra (sacar todas las reliquias), por haver entrado allí unos ladrones cerca de la media noche que les impidieron el trabajo, y fueron causa de que se retirasen los Monges a su alojamiento con la por-

(50) Ibídem. p. 227.

(51) En este mismo aspecto hemos de hacer notar cómo GARCIA VILLADA (Historia Eclesiastica de Estyaña) nos habla del hallazgo de una inscripción gracias a la cual se identifican los huesos hallados en una iglesia de Avila con los del Varón Apostólico San Segundo. Nos refe. rimos, a un suceso ocurrido casi quinientos años después que lo fueron los de San Indalecio en Pechina, y motivo del cual es que a partir de 1595 figure San Segundo como patrono de la diócesis de Avila, unido a los mártires Vicente, Sabina y Cristeta. (p. 166, ob. cit.).

Según el historiador citado, los hechos fueron como sigue: En 1519 al derribar unos operarios una pared de la iglesia de Santa Lucía (tal vez antes la de San Sebastián) hallaron un sepulcro y dentro una caja de madera con huesos humanos (p. 163), en la cual figuraba la inscripción "Sanctus Segundus" (p. 164), cincelada en la caja según uno de los testigos. Otro, en cambio, testifica que la dicha inscripción estaba esculpida en un trozo de piedra en el interior de dicha caja (p. 165).

Como vemos, al igual que en el caso de San Indalecio, también aquí hay una inscripción que identifica los huesos hallados con los del Varón Apostólico, y esto casi quinientos años después como en un principio hemos dicho. 
ción de reliquias que havian recogido" (52). Esto no concuerda con cuanto nos vienen diciendo. Primero ¿Dónde estaban los soldados que custodiaban la puerta? Segundo. ¿Qué venían a hacer los ladrones en el templo? Tercero. ¿Por qué les impidieron seguir su trabajo y sin embargo les permitieron llevarse las reliquias que ya tenían?

Todo lo anterior nos confirma en la tesis que en un principio hemos expuesto: el tal "Templo", no es más que una capilla o iglesia en la que los mozárabes daban culto a un mártir, esto es un antiguo martyrium. El episodio de los ladrones que llegan, es sólo la aparición de un grupo de mozárabes que van a indagar lo que está sucediendo en su iglesia, encontrándose con la depredación de las reliquias del santo que allí se veneran lo que obliga a huir a los monjes con las que ya han conseguido, buscando a continuación la protección de Don García, ya que según el mismo párrafo nos indica: marchando los monjes a su alojamiento y "dando cuenta de todo a Don García, que se hallaba en el Egercito" (53).

Viene a continuación los inicios de la relación de milagros debidos a las reliquias, el primero y más importante, es el de que gracias a su intercesión no se celebra la batalla ante Almería que se iba a dar entre huestes cristianas al servicio de los príncipes del Islam de Sevilla y Murcia.

Dice que "al día siguiente prosiguieron los Monges su tarea, y se apoderaron de todo lo que havia en el sepulcro retirándose a Murcia con las sagradas Reliquias" (54). Esto indica que ya en el siguiente día y al haber una paz que motiva la retirada de los ejércitos, las tropas de Don García protegen a los monjes, antes de su marcha, para que acaben con la depredación de las codiciadas reliquias, retirándose con ellas a sus cuarteles de Murcia.

Siguiendo con los hechos milagrosos, hay unas apariciones del Santo que conmina a los monjes a continuar su marcha hacia el monasterio ante la detención de estos en Murcia.

(52) Ibídem. p. 227.

(53) Ibídem. p. 227.

(54) Ibídem. p. 228. 
Viene después una parte verdaderamente histórica, es la que señala el itinerario que siguen desde Murcia a San Juan de la Peña, que debió ser el camino de los peregrinos que desde estas tierras seguían la ruta de Santiago: Denia-Valencia-Tortosa-Lérida. El mismo carácter ofrece la recepción de las reliquias en el monasterio.

Veamos cuál, estimamos, fue el motivo del relato, aparte de los detalles al gusto de la época.

Primera, tiene por objeto llevar a la seguridad de que se tratan de las auténticas reliquias del Varón Apostólico San Indalecio, lo cual muestra la realidad de la presencia en Hispania de los siete discípulos de San Pedro, y por tanto, que los orígenes de la cristianización de la Península no son debidos a una corriente africana, sino que proceden directamente de Roma, a la cual iglesia debe quedar por tanto vinculada Hispania (55).

Segunda, lleva a demostrar que los hechos milagrosos relatados confirman que los huesos de que son portadores pertenecen a un santo, y que éste no es de la mozarabia, ni nada tiene que ver con ella, ya que manifiestan una voluntad expresa de ser llevados a tierras cristianas, lejos de las que domina el Islam, a pesar de que en esta época haya todavía comunidades mozárabes que mantienen su fe católica, pero sobre las cuales, hay que hacer constar, la influencia de la iglesia romana es muy débil, ya que a pesar de ella mantienen su rito y costumbres (56)

Para terminar esta parte, resumiremos nuestra opinión, de un carácter eminentemente subjetivo y por tanto sujeta a discusión.

(55) DIAZ Y DIAZ, M. C. (En torno a los origenes del cristianismo bispánico. En Las raices de España. Madrid, 1967), trata ampliamente sobre los orígenes del cristianismo en Hispania, haciendo notar los intentos de conseguir para él unas fuentes apostólicas. Demuestra ampliamente su origen norteafricano. En esta misma línea está BLAZQUEZ, J. M. (con TOVAR, A.-Historia de la Hispania romana. Madrid, 1975. p. 185 y sgts.) También Origen africano del cristianismo español, en "Archivo Español de Arqueología". T. 40. 1968. pp. 30-50.

(56) Una muestra de la oposición a la iglesia mozárabe, por los conquistadores, se pone de manifiesto en el hecho ocurrido a raiz de la toma de Toledo, en que conserva aquélla, la más alta prelatura, y que en esta ciudad es elegida por los fieles. Este derecho, que estimaban legítimo, es revocado a raíz de la entrada de los conquistadores que imponen un arzobispo francés, el monje cluniacense Bernardo.-(PASTOR DE TOGNERI, R.-Del Islam al Cristianismo. Barcelona, 1975. p. 116.) 
Creemos que hay un hecho cierto, es el traslado de las reliquias de un santo de nombre Indalecio desde Bayyana a San Juan de la Peña. Que el nombre de este santo hizo que, dada la popularidad que en la época tiene en el norte de la Península el relato de los Siete Varones Apostólicos, fuera identificado con su omónimo, obispo de Urci. Que el San Indalecio de Bayyana es un mártir de estirpe ibérica, muerto durante las persecuciones en Hispania y para veneración del cual, se levanta un martyrium en la inmediación de una villa hispano-romana para ser enterrados junto a él los propietarios de la misma (57). Por último, dados los enfrentamientos entre la iglesia mozárabe y la romana, es del mayor interés político la afirmación de la prelación de Roma en Hispania, la cual queda probada por su evangelización debida a la acción de unos discípulos de los apóstoles Pedro y Pablo.

Hay pues un hecho que, realizado de una manera consciente, debido al azar, o provocado por la histeria de un monje, ha dado lugar a la sustitución de la veneración de un verdadero santo, mártir, por la de un legendario confesor de la fe, que la misma tradición deja la duda de su martirio. Tradición que, hoy tras un cuidadoso examen de la misma se llega a la consecuencia de su carencia de base histórica, como a continuación vamos a ver.

\section{LOS VARONES APOSTOLICOS}

Al tratar de los llamados Varones Apostolicos, Torcuato y sus compañeros (Torquati et comitum), lo primero que deberemos hacer es un estudio de las fuentes que sobre ellos tratan, las cuales, como veremos, están ligadas a la traslación del cuerpo del apóstol Santiago a España,

(57) Se podría comparar esta obra con el Martyrium de la Alberca (Murcia) estudiado por Palol, quien le fecha en la primera mitad del s. IV, suponiéndole una sepultura familiar con los cuerpos cerca del relicario del santo (PALOL, P. de.-Arqueología cristiana de la España rcmana. Madrid-Valladolid, 1967, pp. 106 a 114.) 
pues no en balde en más de un santoral figuran como "discípulos de Santiago" (58).

Haremos primero una exposición cronológica de aquellos escritos que se refieren, al traslado del cuerpo del Apóstol y su relación con los Varones Apostólicos, así como también de aquellos otros que tratan específicamente de éstos. Pasaremos luego a buscar la interrelación de las fuentes expuestas, y por último se tratará de obtener las consecuencias que de este estudio se deriven. Terminada ésta a modo de introducción trataremos exclusivamente de los Siete Varones.

Enumeremos, pues, estas fuentes :

1) Catálogos Bizantinos del s. VII (59). En unos se afirma que el Apóstol fue enterrado en Jerusalén, en otros que en Cesarea de Palestina, algunos que en Marmarica. García Villada supone que esta última se refiera a la región de este nombre comprendida entre Cirenaica y Egipto $(60)$.

Como vemos en ninguno de estos catálogos figura la región galáica, si bien esto fue subsanado por los escritores medievales hispanos del s. IX, ya que la voz Marmarica la interpretaron por marmoricis (mármol) y si a ésta se le antepone Acaya o arca (con la que fue traducida al latín la palabra griega que, antes de Marmarica, figura en un manuscrito de Vatoped en el Monte Atos) dará el conjunto "Arcis Marmoricis" o sea "Arca de Mármol" (61). El resultado ha sido que el nombre de lugar ha sido sustituido por la forma del enterramiento. Así en vez de haber sido Santiago enterrado en la ciudad o región de Marmarica, pasó a serlo en el interior de un arca de mármol.

(58) En cuanto a los orígenes del culto al Apóstol Santiago en España, es de interés la hipótesis de Pérez de Urbel, así de cómo llegaron las reliquias a Galicia desde Mérida (PEREZ DE URBEL, Fray Jlsto. Los primeros siglos de la Reconquista. En T. VI. La España Cristiana, de la Historia de España dirigida por MENEZDEZ PIDAL.-Madrid, 1964).

(59) GARCIA VILLADA. p. 79.

(60) Ibídem. p. 80.

(61) Ibídem. p. 80-81. 
2) Supuesta narración, perdicla, en la que se relata cómo hacia el año 814 fue descubierta la tumba del Apóstol. Hecho testificado por Teodomiro obispo de Iria. De la cual narración, se derivaría la carta atribuida al Papa León III (62) contemporáneo de estos hechos y en la cual figura cómo el cuerpo del Apóstol es trasladado milagrosamente, por siete discípulos y en siete días, desde el lugar de su martirio, a Iria, enterrándole 12 millas al interior de la costa "bajo las arcas marmóreas". Después cuatro de los siete discípulos regresan a Jerusalén y los otros tres, Torcuato, Tesifonte y Atanasio (nombres, los dos primeros coincidentes con los de dos de los Varones) quedan en Galicia (63).

3) Martirologio de Floro. Redactado entre los años 808 y 838 ; y el de Adón de los años 850 a 860 compuestos ambos en Lyon. El segundo repite a la letra lo que, a Santiago se refiere, en el primero. En ambos se especifica que los huesos del Apóstol fueron "trasladados a España y guardados en los últimos de sus confines, es decir, frente al mar Británico" (64)

Los orígenes de esta noticia García Villada los supone son la consecuencia directa de la difundida entre la cristiandad del descubrimiento del sepulcro del santo en Galicia, haciendo notar además que en la primitiva redacción del Martirologio de Floro, escrita en el primer tercio del 3 IX esta noticia no figura, siendo por tanto un añadido posterior (65).

4) Manuscrito de Silos, del s. IX, hoy en el British Museum. En él hay formularios especiales para el oficio y misa de los Varones Apostólicos. Vives (66) hace constar que, compulsado con otra recensión conservada en un manuscrito del s. VII-VIII (el Oracional Tarraconense, hoy en Verona) en sus nueve décimas partes lo reproduce con toda exactitud. Al

(62) De ésta se tienen noticias por tres manuscritos: el de San Marcial de Limoges (s. IX); otro conservado en El Escorial (s. XII); y el Códice Calixtino (s. XII). (GARCIA VILLADA, op. cit. p. 87).

(63) GARCIA VILLADA. p. 85-86.

(64) Ibídem. p. 82.

(65) Ibídem. p. 82.

(66) VIVES. Tradición y leyenda... p. 502. 
no encontrarse en éste, el más antiguo, la menos referencia a los Varones, hace suponer que la noticia sobre los hechos de éstos es posterior a la redacción del manuscrito.

5) Martirologio de Lyon, de principios del s. IX. En él se conmemora la fiesta de Torcuato y sus compañeros. Al igual que en el anterior Vives (67) señala que en el Martirologio de Beda, que fue su modelo, no aparece referencia a los Varones y lo mismo sucede con el Jerominiano, más antiguo, del s. VI-VII.

6) Pasionario de Cardeña, del s. X. Considerado por Vives (68) como la fuente más antigua, en la que se narra la venida a Hispania de los Siete Varones, dándonos sus nombres y explicando que tras haber sido consagrados obispos en Roma por San Pedro y San Pablo, vienen a evangelizar Hispania; y como, tras los hechos ocurridos en Guadix, logran la conversión de los paganos; luego se establecen en siete ciudades (69).

7) La literatura hagiográfica que García Villada menciona (70): el Martirologio de Lyon, la Vida compendiada por el Cerratense, la Misa Apostólica. Todos los cuales, con muy pocas diferencias, siguen los h?chos, referentes a los Varones, narrados en el Manuscrito de Cardeña.

8) Manuscrito del s. XII, procedente del monasterio de San Pedro de Glembours, hoy en la Biblioteca Real de Bruselas (71). En él se relata cómo los discípulos del Apóstol, tras desembarcar portando su cuerpo

(67) Ibídem. p. 503.

(68) Ibid. p. 497.

(69). Referente a estos hechos, figura el texto latino del Pasionario en VIVES ( La "Vita Torquati et comitum" en Analecta Sacra Tarraconensia. Vol. XX. 1947) como apéndice al artículo mencionado. También en GARCIA VILLADA (op. cit. p. 151-52) aparece una recesión castellana de lo que las diversas fuentes dicen sobre los Sicte Varones, su llegada a Acci y pos-
terior asentamiento.

(70) GARCIA VILLADA. p. 151.

(71) Manuscrito 5.333.35. En él figura la "Traslatio S. Jacobi in Hispaniam". (HUIDOBRO Y SERNA, L.-Las peregrinaciones jacobeas. Madrid, 1950. T. I. p. 77). 
en las costas de Galicia, les acontece una serie de hechos, antes de darle sepultura, que ofrecen una gran semejanza con lo que les sucede en Guadix a los Siete Varones y que el Pasionario de Cardeña relata (72).

9) Libro Calixtino (s. XII), que se supone compuesto por el Papa Calixto II (119-24). En él aparece una relación detallada de la traslación del cuerpo de Santiago y en el que figuran los nombres de los Siete Varones Apostólicos como discípulos del Apóstol (73). Se especifica cómo los discípulos, que son nueve, embarcan en Jafa portando las sagradas reliquias, alcanzando las costas gallegas y enterrándolas en Libredon, donde quedan custodiándolas dos de ellos, Teodoro y Atanasio, que después serán enterrados a ambos lados del Apóstol; los otros siete cuyos nombres son los de los Varones, marchan a Roma y tras ser ordenados obispos regresan a Hispania a predicar el Evangelio (74). La narración de

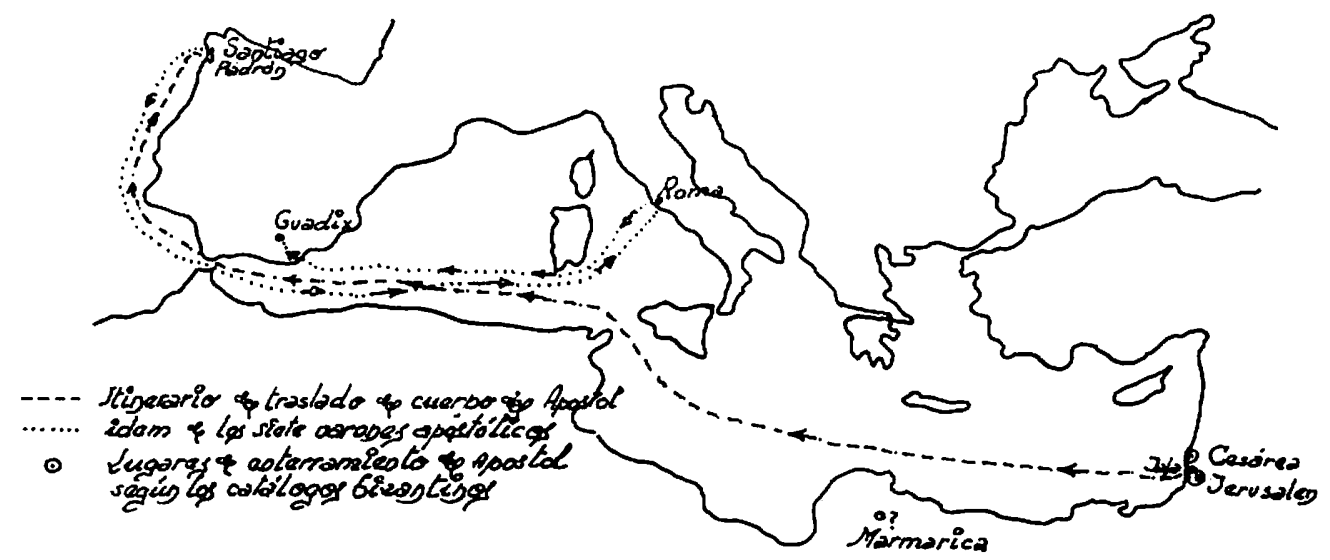

Mapa en el que figuran los supuestos enterramientos del Apóstol Santiago según los Catálogos Bizantinos del s. VII. También quedan señalados los itinerarios seguidos por los discípulos del apóstol, llevando su cuerpo desde Jafa a Iria (Padrón) -en siete dias- según el Códice Calixtino - s. XII- y los de siete de ellos (los Varones Apostólicos) desde Padrón a Roma y luego ya obispos a Acci (Guadix).

(72) GARCIA VILLADA. p. 86

(73) Ibídem. p. 86.

(74; HUIDOBRO. p. 72. 
estos hechos le hace suponer a García Villada la existencia de un cierto parentesco entre el relato de la traslación y las Actas de los Varones Apostólicos.

Haciendo un resumen de las fuentes que acabamos de reseñar podemos plasmarlas en el cuadro comparativo adjunto en el que hay que hacer notar :

CUADRO CRONOLOGICO Y TEMATICO DE LAS FUENTES QUE TRATAN DEL TRASLADO DEL CUERPO DE SANTIAGO Y DE LOS SIETE VARONES APOSTOLICOS

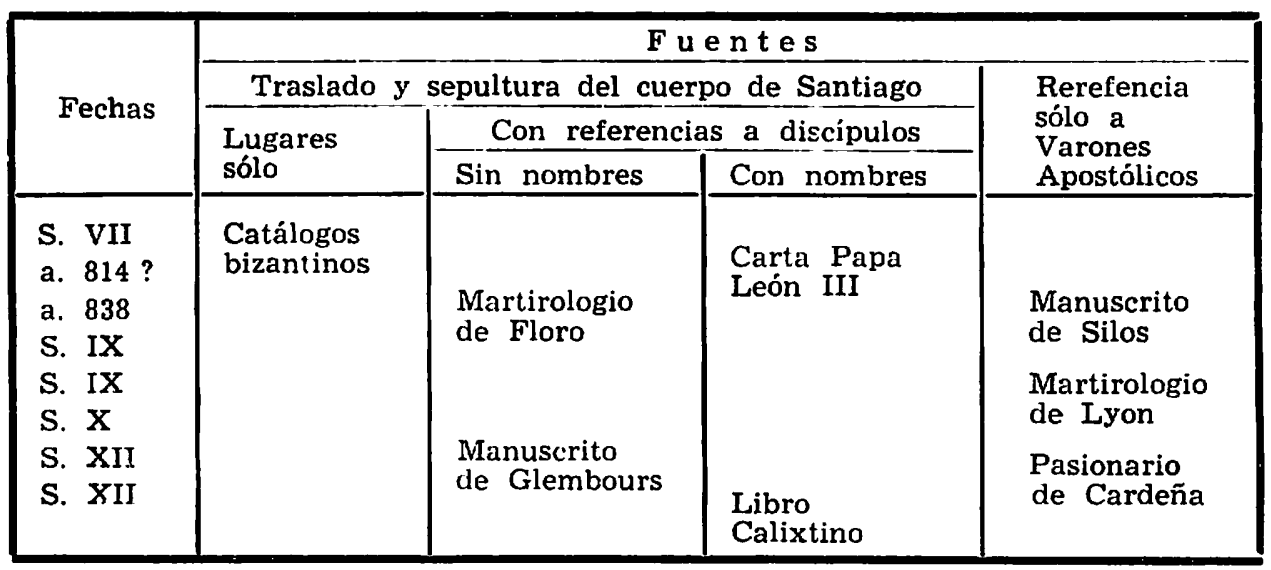

A) Como en las fuentes más antiguas, Catálogos Bizantinos, para nada se habla de Galicia.

B) El que tras el hallazgo de la tumba del Apóstol (814?), de la cual las referencias más inmediatas se contienen en el Manuscrito de Limoges, del mismo s. IX, comienzan las noticias de los Varones como discípulos de Santiago, figurando los nombres de dos de ellos, Torcuato y Tesifonte, en dicho texto. 
C) Dentro del s. IX aparece ya una diversificación en las fuentes: una, el Martirologio de Floro, y los que en él están basados se refieren de una manera concisa al traslado del cuerpo del Apóstol; en otras, el Manuscrito de Silos y el Martirologio de Lyon nos hablan del Oficio de los Varones Apostólicos y de la fiesta de Torcuato y sus compañeros.

D) Será, sin embargo, en el s. X, cuando el Pasionario de Cardeña nos remita las primeras noticias referentes a la llegada a Hispania de los Siete Varones y de su acción evangelizadora.

E) En el Manuscrito de Glembours, ya en el s. XII, encontramos una repetición en lo fundamental de los hechos acaecidos en Guadix a los Siete Varones, pero trasplantados a la comarca de Iria en Galicia.

F) Para finalizar, en el Libro Calixtino ya encontramos un intento claro de unificación de las dos relaciones, la del traslado del cuerpo del Apóstol y la de los hechos de los Siete Varones, estableciendo una continuidad entre ambos. Tal ilación es incluso admitida por alguno de los que tratan este tema, dándole una cierta explicación (75).

Como una aclaración, a cuanto llevamos dicho, presentamos el esquema adjunto en el que se manifiesta la relación entre la traslación del cuerpo del Apóstol y los hechos de los Varones apostólicos. En él podemos ver cómo a partir de una fuente primitiva, sobre la traslación de Santiago, nace una tradición que con el Manuscrito de Cardeña (s. X) se manifiesta ya totalmente independiente de la primera, pero que más tarde, en el s. XII, por el redactor del Libro Calixtino, vuelve a ser unida a la primitiva.

(75) HUIDOBRO (ob. cit. p. 79) da la explicación, que sigue, al hecho de que una vez enterrado el cuerpo del Apóstol, y marchar a Roma sus discípulos (los Siete Varones), a su regreso a Hispania "todos quedaron en la Bética", dice: "La razón parece obvia Comenzaban a suscitarse las persecuciones contra los cristianos, y éstas se recrudecían en la España Tarraconense; $\because$ aunque nuestros santos no rehuyeran la palma del martirio, no era tampoco prudente reanudar șu misión entregándose voluntariamente al tirano. De ahí que sc establecieran en el Sur, donde parece que la vida era más tranquila." 
ESQUEMA CON LA INTERRELACION DE LAS FUENTES QUE TRATAN DEL TRASLADO DE LAS RELIQUIAS DE SANTIAGO Y DE LOS VARONES APOSTCLICOS

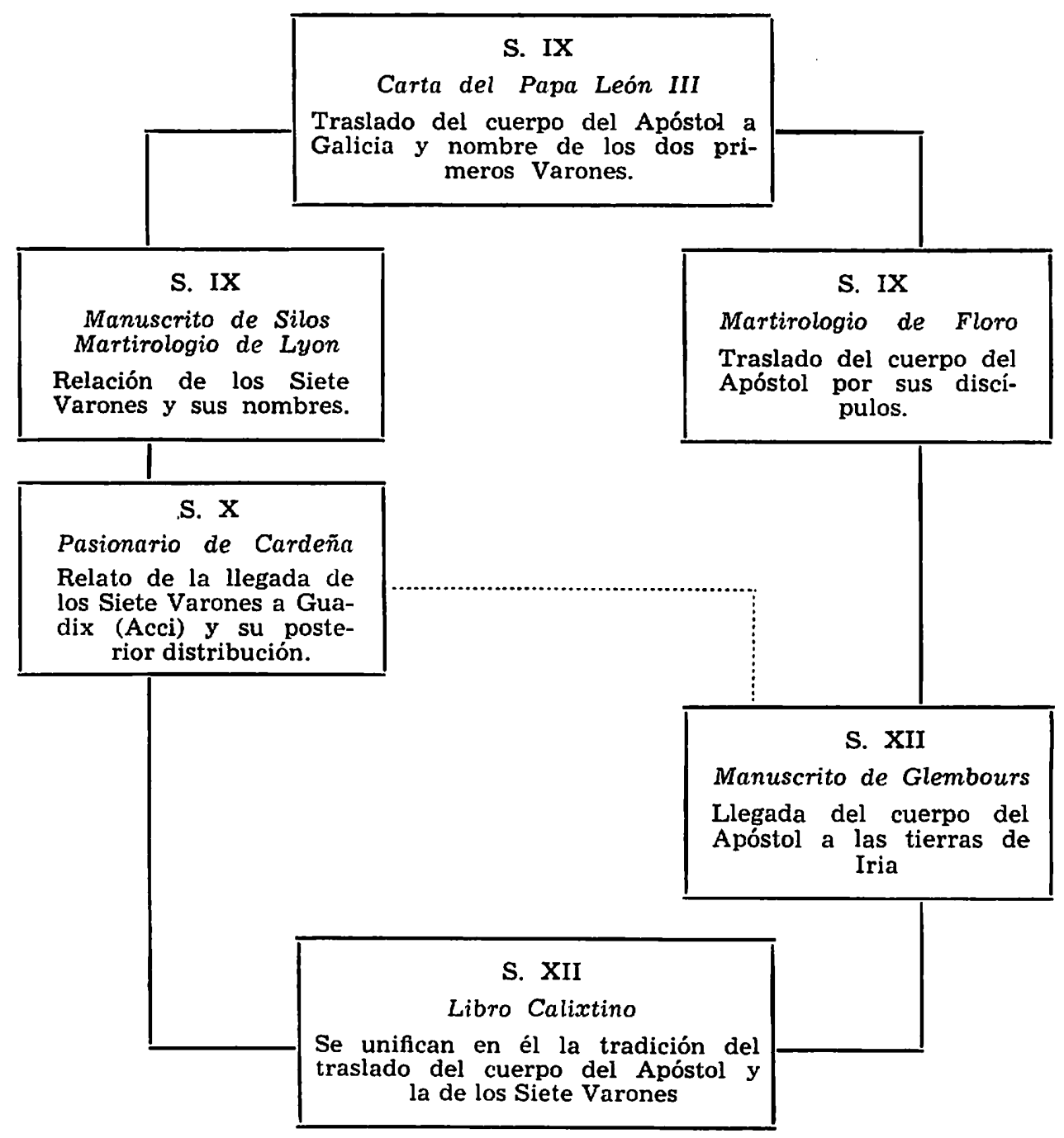


Todo ello nos lleva a considerar la hipótesis de Vives de que esta tradición de los Varones Apostólicos, de su llegada a Guadix, y posterior asentamiento en siete ciudades fue escrito en el norte de la Península (76). De acuerdo con este historiador, creemos que el autor de la relación que se transmite en el Manuscrito de Cardeña, debió vivir en los reinos del norte, conociendo perfectamente la tradición del traslado del cuerpo del Apóstol, pero siendo posiblemente originario del sur, un mozárabe, estableció los orígenes de la cristianización de Hispania en su tierra. En la primitiva redacción de los hechos que relata, utilizó los nombres de alguno de los discípulos de Santiago que figuraban en el relato de la traslación. En cuanto a los lugares, en que decía establecieron sus sedes, lo fueron en ciudades o aldeas por él conocidas, con lo cual algunas de ellas tomaban el carácter, no solamente de sedes episcopales, sino también de ser los orígenes, a partir de las cuales se cristianizó Hispania. Todo ello hace que, adelantando las conclusiones finales de este trabajo, se considere que la tradición procedente del Manuscrito de Cardeña no es más que una leyenda.

Tras ésta, a modo de introducción, pasemos a tratar con una cierta exclusividad de los Siete Varones Apostólicos.

La tradición cuenta cómo tras desembarcar en las costas de Hispania, llegan a cierta distancia de Guadix, enviando sus discípulos a comprar comida a esta ciudad. Salen contra ellos los gentiles, que aquel día celebraban la fiesta de Júpiter y Mercurio, en ademán amenazador. Retroceden los Varones hasta la orilla del río, y al pretender los paganos alcanzarles y cruzar el puente, se derrumba éste, pereciendo ahogados todos los perseguidores. Ante esto, cunde el pánico en los habitantes de Guadix, y una noble dama llamada Luparia envía a preguntar a los Varones cuál era la causa de su venida, al conocerla, recibe el bautismo y luego construye una iglesia. Después el pueblo se convierte a la fe de Cristo $(77)$.

(76) VIVES. Tradición y leyenda... p. 506.

(77) GARCIA VILLADA. p. 152. 
Si de una manera racional examinamos los hechos anteriores, encontramos por un lado, ciertas lagunas, por otro un exceso de detalles, así como un excesivo aire de leyenda, todo muy del gusto de la época en que fue escrita la narración.

En primer lugar, el autor del relato omite, de una manera inexplicable, cuál fue el lugar donde desembarcaron los Siete Varones y también dónde comenzaron la evangelización, ya que nos habla de cómo los varones enviaron, sus discípulos a Acci, en busca de alimentos. Debemos preguntarnos: ¿De dónde proceclían estos discípulos? ¿Les venían acompañando desde Roma o procedían de alguna parte de Hispania? Nosotros debemos suponer, que si los Siete Varones Apostólicos venían con una misión evangelizadora, ésta debió comenzar desde el primer momento en que pusieron pie en la Península, y de aquí procederían los primeros discípulos que les acompañaban. Ahora bien, el que el relato comience precisamente en Guadix, tan al interior, debe hacer suponer que, por alguna causa, fue omitida la mención de los lugares en que primero estuvieron, o bien que éste empieza con el primer éxito obtenido que da lugar a la conversión de toda una ciudad (78).

En cuanto a la mala acogida que en Acci se tributa a los discípulos de los Varones, cabe darle una total credibilidad, ya que su presencia sig-

(78) A estc respecto, debemos hacer notar, otra vez, la semejanza de los hechos que suceden en Galicia con ocasión de la llegada a sus costas del cuerpo del Apóstol llevado por sus discípulos, según el relato que figura en el manuscrito de Glembours, y de los que a continuación damos cuenta:

Llegados en barco a Padrón, los discípulos de Santiago, con el cuerpo de éste, fueron a pedir a una rica dama llamada Lupa o Luparia (según los documentos) un lugar en sus propiedades para enterrarle. Esta dama, que era pagana, les envió al rey de aquellas tierras, quien quiere matarles. Al huir los discípulos, con las reliquias del Apóstol, penetran en una cueva, la que se derrumba matando al rey y sus secuaces. En escritos posteriores, lo que se derrumba es un puente, con los mismos efectos. Este prodigio no convence a Luparia, la que, para librarse de los recién llegados, los envia al monte Ilicino a que cogiesen unos bueyes para transportar el cuerpo del Santo. Estos, que eran toros bravos, se amansan y dejan uncir. También los discípulos matan a un dragón que aterrorizaba la comarca. Ante tantos prodigios, Luparia se convierte, destruye el templo pagano y los ídolos que en él había y en su lugar levanta un mausoleo para Santiago. (GARCIA VILLADA, p. 86).

Como vemos, todo lo anterior no es más que una transposición a Galicia de los hechos, relatados en cl manuscrito de Cardeña, sucedidos en Acci. A estos se les han añadido dos prodigios más: el amansamiento de los toros bravos; la muerte del dragón. 
nificaba la interrupción de unos actos de culto por unos extranjeros, sien. do lógica su ibérica reacción. Por lo que cabe al hundimiento del puente, y sobre todo el que perezcan ahogados los que estaban cruzándolo, ya ofrece más graves dudas. Bien que suponiendo se tratase de un viejo puente de cuerdas o madera, ante el peso de los que sobre él se aglomeran, se hundiese, pero de ahí a que todos pereciesen ahogados va una gran diferencia. Pese a los cambios climáticos, no creemos en el gran caudal del río Acci, capaz de arrastrar la muchedumbre que nos hacen ver, a no ser que hubiese una riada provocada por unas grandes lluvias, de las cuales el relato nada dice.

La posterior conversión de Luparia, y de toda la población de Acci, debida al terror que les ha inspirado lo acontecido, cae dentro de la más pura narrativa medieval, en que las conversiones son más debidas a hechos inexplicables, milagros, que a la palabra evangélica.

Así, pues, para terminar, esta narración creemos cae más bien dentro de la literatura medieval, considerando difícil, si no imposible, esté basada en otra anterior sobre todo procedente del s. I.

Tras la evangelización de Acci viene la distribución de los Varones en una zona en la que fundan sus sillas episcopales, y que queda determinada por las localidades a que la tradición hace referencia y que suponemos estar situadas en los lugares señalados: Torcuato queda en Acci (Guadix), Cecilio en Iliberris (Elvira), Eufrasio en Iliturgis (Cuevas de Lituergo) (79), Indalecio en Urci (Aguilas ? ), (80), Segundo en Abula

(79) En la identificación de estas tres ciudades, no parece haber problema, pues en ella están de acuerdo todos los historiadores que se han ocupado de este tema.

(80) GARCIA VILLADA (ob. cit. p. 160) concluye, que estaba situada en la llamada Torre de Villaricos, tras hacer un rápido análisis de las menciones que de esta ciudad hacen Marciano Capela, Pomponio Mela, Plinio, y la del Itinerario de Antonino. Desde que según las investigaciones del arqueólogo SIRET (Villaricos y Herrerias.-Memorias de la Rea Alcademia de la Historia. Madrid, 1906. pp. 381 a 83) y de la descripción que aparece en la obra de EDRISI (Description de l'Afrique et de l'Espagne (traduction et notes de Dozy et Goeje) Leiden, 1968. p. 194 del texto y p. 236 de la traducción) se puede identificar plenamente a la actual Villaricos con la antigua Baria, no cabe ubicar por tanto en aquélla a Urci.

Hoy la gran mayoría de los historiadores la fijan en Pechina (próxima a Almería). Noso- 
(Abla) (81), Tesifonte en Vergi (Berja ? ), (82), y Hesiquio en Carcesa (Cieza? ).

Si situamos en un mapa todas estas supuestas sedes, en aquellos lugares de ubicación más probable, nos darán un área que coincidirá con la de la primera evangelización de Hispania. Esta deberá ser rica en testimonios arqueológicos, también aquéllas fuentes que se refieran a la evangelización de la Península hablarán de ella.

Pero resulta que, en cuanto a las fuentes se refiere, las menciones de los lugares de esta región son escasos, no pudiéndose comparar con los referentes a otras de la Península. Según la historiografía actual representada por los escritos de historiadores de solvencia, hace bien constar cómo, los primeros testimonios escritos de la existencia de cristianos en Hispania; son de finales del s. II, basándose en los testimonios de Tertuliano e Ireno, en documentos que datan de los años 200 a 180. También en la carta 65 de San Cipriano obispo de Cartago, del año 254, en la que se demuestra la existencia de comunidades cristianas en Astorga, León,

tros disentimos aduciendo, entre otros, varios de los motivos expuestos en este trabajo. De momento y hasta que aparezcan nuevos datos, que lo confirmen o desmientan, damos como más probable la situación de Urci en el solar que ocupa hoy Aguilas, donde autores del s. XVIII y datos sobre su fundación nos hablan de las ruinas romanas que allí habían (GARCIA ANTON. El puerto de las Aguilas (ss. XV-XVII). En Murcia (Revista de la Diputación), n. ${ }^{\circ}$ 8. 1976. nota 1$)$.

(81) GARCIA VILLADA (ob. cit. pp. 161-67), tras un exhaustivo análisis sobre la identificación de esta sede, en la que deshecha, de manera contundente, su identifcación con Avila, termina situándola en Abla (Almería), opinión que sigue TARRADELL MATEU (España Antigua. En Historia de España y América social y económica, dirigida por Vicens Vices. Barcelona 1974. Vol. I, p. 170) y con la que estamos plenamente de acuerdo.

(82) Para el P. FITA (Vergilia ciudad bastetana en Albuniel de Cambil en B.R.A.H. T. LXV. Madrid, 1914. pp. 580-81) se encuentra en las proximidades de Albunicl de Cam. bil (Jaén). GARCIA VILLADA (ob. cit. p. 160) aduce razones de peso para situarla en Berja (Almería), entre otras las ruinas romanas que aparecen en la Villa Vieja, y la aparición de un sarcófago cristiano. De acuerdo con este historiador nos inclinamos a situar Vergi en Berja.

(83) El P. FITA (ob. cit. p. 581) la supone en Carchel, sucesora del Carachuel de la Hitación de Wamba y de la Karka de Tolomeo.

GARCIA VILLADA (ob. cit. p. 161), en el análisis que hace, sigue la opinión del P. Fita en cuanto a la evolución del nombre, pero disiente en la situación geográfica, llevando Carcesa a Cieza. Crcemos está en lo cierto, pues precisamente a muy poca distancia de esta ciudad hay ruinas de obras al parecer romanas. 
Mérida y probablemente en Zaragoza (84). Además esta carta es importante, ya que es el primer indicio de una procedencia norteafricana de la iglesia peninsular, la cual, podemos decir, se afirma con los diversos detalles que aparecen en las actas del Concilio de Elvira del primer decenio del s. IV (85).

Este origen africano de la iglesia de Hispania pudo ser debido a las intensas relaciones comerciales de la Península con las vecinas costas africanas. Así se sabe que San Félix llegó de Africa a Cataluña disfrazado de mercader, predicando en Barcelona, Ampurias y Gerona, también "el Breviario de la Diócesis de Barcelona, recogiendo tradiciones antiguas, describe a San Cucufate o Cugat, como africano, nacido en Scillas" y que vino desde Africa a Barcelona (86).

Por otro lado la procedencia de los mártires, cantados por San Prudencio que fueron víctimas de la persecución de Diocleciano, puede servirnos para indicar los progresos de la cristianización en esta época. "Barcelona, Gerona, Zaragoza, Valencia, Calahorra, León, Mérida, Sevilla, Alcalá de Henares, Córdoba y Toledo" (87) son los lugares mencionados. Como se ve, la cristianización se va fijando en las ciudades de la costa o situadas sobre las grandes vías de comunicación.

Más adelante, entre las poblaciones que figuran en las actas del Concilio de Elvira, se precisa una notable concentración en la Bética. Respecto a las siete ciudades, sedes de los Varones Apostólicos, cuatro de éstas aparecen, la propia Iliberris, Acci, Urci, Iliturgi.

Según, pues, las fuentes documentales a que nos hemos referido, dos hechos destacan : uno el posible origen de la cristianización de la Pe-

(84) BLAZQUEZ, J. M. Origen del cristianismo en Esñapa, en Historia de la Hispania Romatu, de TOVAR, A. y BLAZQUEZ, J. M., Madrid, 1975. pp. 185-86.

(85) Detalles que hace resaltar BLAZQUEZ (ob. cit. p. 187): "existencia de unas comunidades regidas por presbíteros, uso conocido en ciertas zonas de Africa"; "la costumbre de que el ministro de la penitencia canónica sea el obispo"; por último el rigorismo africano de la disciplina de los padres reunidos en Elvira.

(86) BLAZQUEZ. p. 187.

(87) Ibídem. p. 187. 
nínsula debido a una corriente norteafricana, opinión cada vez más extendida entre los historiadores actuales que se ocupan del problema; otro las escasas menciones, nulas en las primeras fuentes, de las ciudades, supuestas sedes de los Varones Apotólicos, como focos de difusión del cristianismo o como lugar de predicación u origen de mártires.

En cuanto al aspecto arqueológico del problema, de los indicios que éste nos suministra, nada mejor que seguir a Palol, quien ha estudiado detenidamente los hallazgos paleocristianos, realizando una labor de síntesis, agrupándolos en mapas del mayor interés. De entre ellos nos vamos a referir al I que titula "Necrópolis romanas tardías y cristianas" (88). A la vista de él podemos sacar las siguientes consecuencias: Frente a una notable proliferación de hallazgos en la Bética e incluso en la parte meridional de la Lusitania, aparece una gran dispersión en Levante y sólo un discreto agrupamiento en el Sureste, la zona que se supone fue evangelizada por los Varones Apostólicos, por tanto la primera en cristianizarse de Hispania (89). Hay, por último, una agrupación digna de notar en Cataluña, sobre todo en la zona costera.

Cuando Palol se refiere al mapa del que nos ocupamos, le considera como el más incompleto de los que publica, pensando que tal vez será pronto superado pues "la gran abundancia de datos y de materiales de excavación, la frecuencia de hallazgos sueltos, de tumbas de cronología inconcreta o de conocimiento y catalogación deficiente por parte de los investigadores; la falta de noticias de múltiples hallazgos de este tipo, considerados sin interés; la falta de publicación de los mismos $\mathrm{y}$, sobre todo, la falta de sistemáticas excavaciones de los grandes conjuntos funerarios, excepto en la parte de la necrópolis cristiana de Tarragona,

(88) PALOL, P.-Demografía y arqueología bispánicas de los ss. IV al VII. (Ensayo de cartografía) en Boletín del Seminario de estudio de arte n..$^{\circ}$ XXXII. Valladolid, 1966, pp. 9 y 23 a 32.

(89) Detallamos, a continuación, en la región que pudiéramos llamar de los Siete Varones, aquellos lugares que figuran en el Mapa I, de PALOL (ob. cit.) agrupados según el signo gráfico que les corresponde: Alicante, Cartagena, Mazarrón, Baeza, Granada (necrópolis con restos epigráficos sueltos); La Alberca (Murcia) (Necrópolis e inscripciones monumentales o de reliquias); Cehegín, Toya (Granada), Guadix (Inscripciones monumentales). 




Croquis en el que figuran los mártires españoles en los tres primeros siglos del cristianismo, según Prudencio y los calendarios mozárabes (extraído de García Villada).

A este croquis se le han añadido, destacándolas, las supuestas sedes de los Siete Varones Apostólicos.

Es de destacar cómo las ciudades con mártires se extienden especialmente por las grandes vías de comunicación. Así: Tarragona por Zaragoza a Braga; Zaragoza a Lisboa por Toledo y Mérida; Sevilla a Córdoba por Ecija. También en los puertos de mayor tráfico en la fachada mediterránea, y Lisboa en la atlántica.

Se señalan como núcleos más importantes de mártires que reflejan una cristianización más amplia: la costa de la Tarraconense y su via hacia el interior, y el de la Bética sobre el Guadalquivir.

Hay que hacer notar el vacío de mártires en el área determinada por las ciudades de los Siete Varones, en la que por su antigüedad la cristianización debía haber sido más amplia. 
hacen este primer mapa nuestro muy incompleto" (90). Ello quiere decir que sólo podemos considerar este mapa como una guía a falta de otra que abarque todos los hallazgos, publicados o no. Sin embargo, gracias a él, podemos darnos una idea de la extensión de la cristianización y por tanto obtener unas primeras consecuencias, cuales son: la importancia de

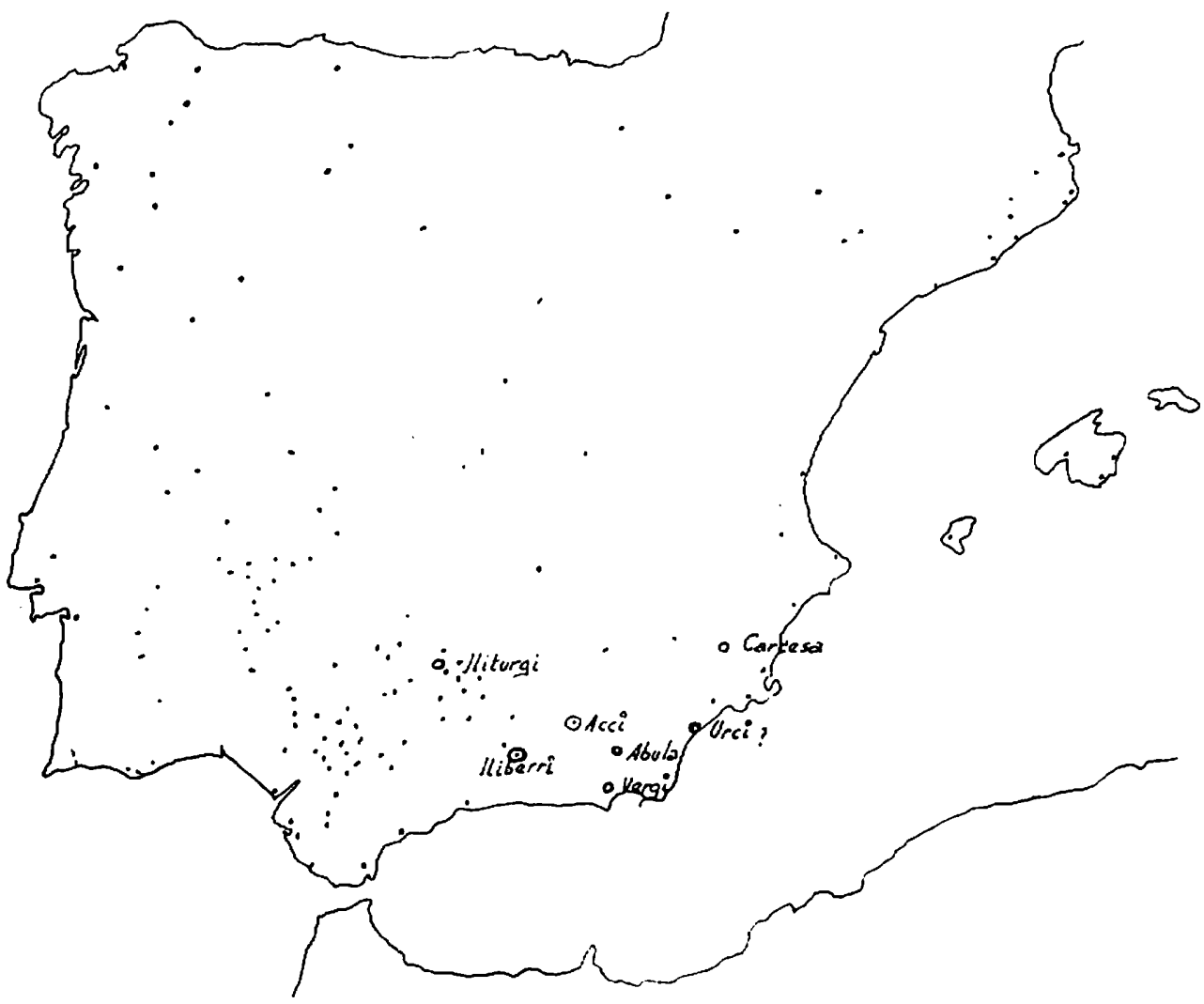

"Mapa de necrópolis romanas tardías y cristianas", según Palol.

A éste se le han agregado los lugares identificados con las supuestas sedes de los Siete Varones Apostólicos. Como se puede observar sólamente en Acci y Elvira hay indicios arqueológicos.

(90) PALOL. p. 8 
los grandes focos de la Bética y de la Lusitania, así como también la parte costera de la Tarraconense; la dispersión general de los otros hallazgos; por último el muy discreto agrupamiento de las tierras en que se supone actuaron los Siete Varones, a pesar de que Palol se refiera a ello como digno de tenerlo en cuenta (91). En cuanto al aspecto estilístico,

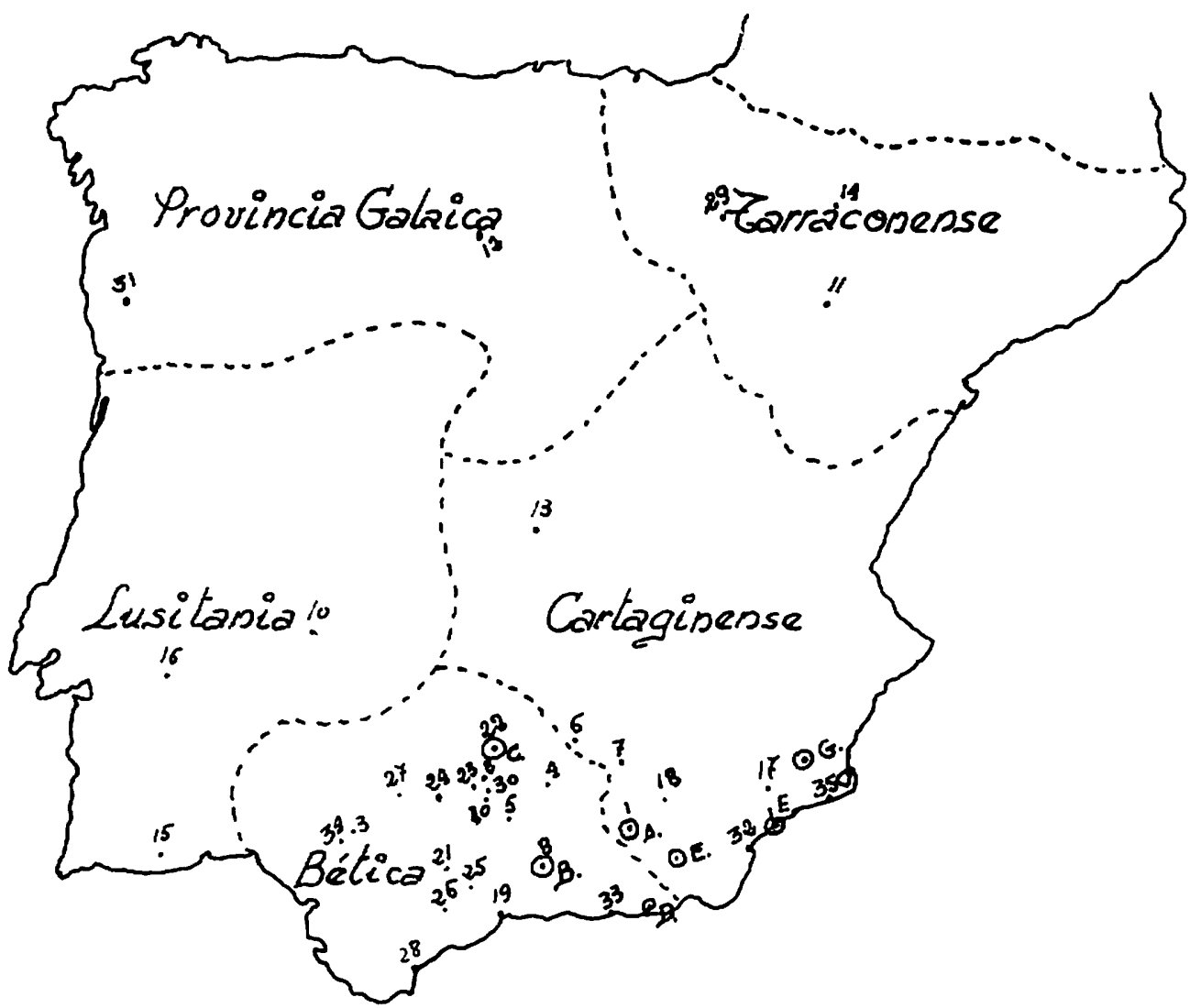

Iglesias representadas en el Concilio de Elvira (300-306) y supuestas sedes de los Varone Apostólicos. De estas últimas figuran en las actas del Concilio: Acci, Elvira, Urci, cuyos obispos Félix, Flaviano y Cantonio ostentan su representación; también aparece Iliturgi, que lo es por el presbítero Mauro.

(91) Ibídem. p. 9. 


\section{REPRESENTADAS POR OBISPOS}
1. Acci - Guadix
2. Córdoba (también Presbitero)
3. Hispalis - Sevilla
4. Tucci (Gemella, según Blázquez) - Martos (también Presbitero)
5. Egabro - Cabra (también Presbítero)
6. Cástulo - Cazlona (también Presbítero)
7. Mentesa - La Guardia
8. Elvira - Granada
9. Urci - Aguilas ? (también Presbitero)
10. Mérida
11. Caesaraugusta - Zaragoza
12. Legio - León
13. Toledo
14. Fibularia - Loarre
15. Ossonoba - Faro
16. Elbora - Evora
17. Eliocroca - Lorca (también Presbitero)
18. Basti - Baza
19. Malaca - Málaga

\section{REPRESENTADAS POR PRESBITEROS}

20. Epora (Ipagro ?) - Aguilar de la Frontera

21. Ursona - Osuna

22. Iliturgi - Cuevas de Lituergo

23. Cárbula - Almodóvar del Río (s/. Bálzquez)

24. Astigi - Ecija

25. Ateva - Teba la Vieja (s/. Bázquez)

26. Acipino - Ronda la Vieja (s/. Blázquez)

27. Lauro - Lora

28. Barbe (Barbesula ?) - Torre de Guadiaro (s/. Blázquez) - Ayune - ?

28. Barbe (Barbesula ? ) - Torre de Guadiaro (s/. Blázquez) - Ayune - ?

29. Municipio - Calahorra (s/. Vives) - Segalvina - ?

30. Ulia - Montemayor ( $\mathrm{s} /$. Blázquez)

31. Drona - Braga (s/. Vives)

32. Baria - Vera

33. Solia (Suel ?) - entre Adra y Almuñécar (s/. Blázquez)

34. Ossigi (Osset ?) - San Juan de Aznalfarache (s/. Blázquez)

35. Cartagena.

- Las iglesias figuran en el mismo orden en que sus representantes firman las actas. (VIVES, J. Concilios Visigóticosı.

- Las identificaciones dudosas, se ha seguido a BLAZQUEZ, J. M. (La Romanización, T. II. Apéndice. Madrid, 1975). 


\section{SEDES DE LOS VARONES APOSTOLICOS}

A. Acci - Guadix (representada en el Concilio de Elvira)

B. Iliberri - Granada (íd. íd.)

C. Iliturgi - Cuevas de Lituergo (id. íd.)

D. Vergi - Berja

E. Abula - Abla

F. Urci - Aguilas ? (íd. íd.)

G. Carcesa - Cieza.

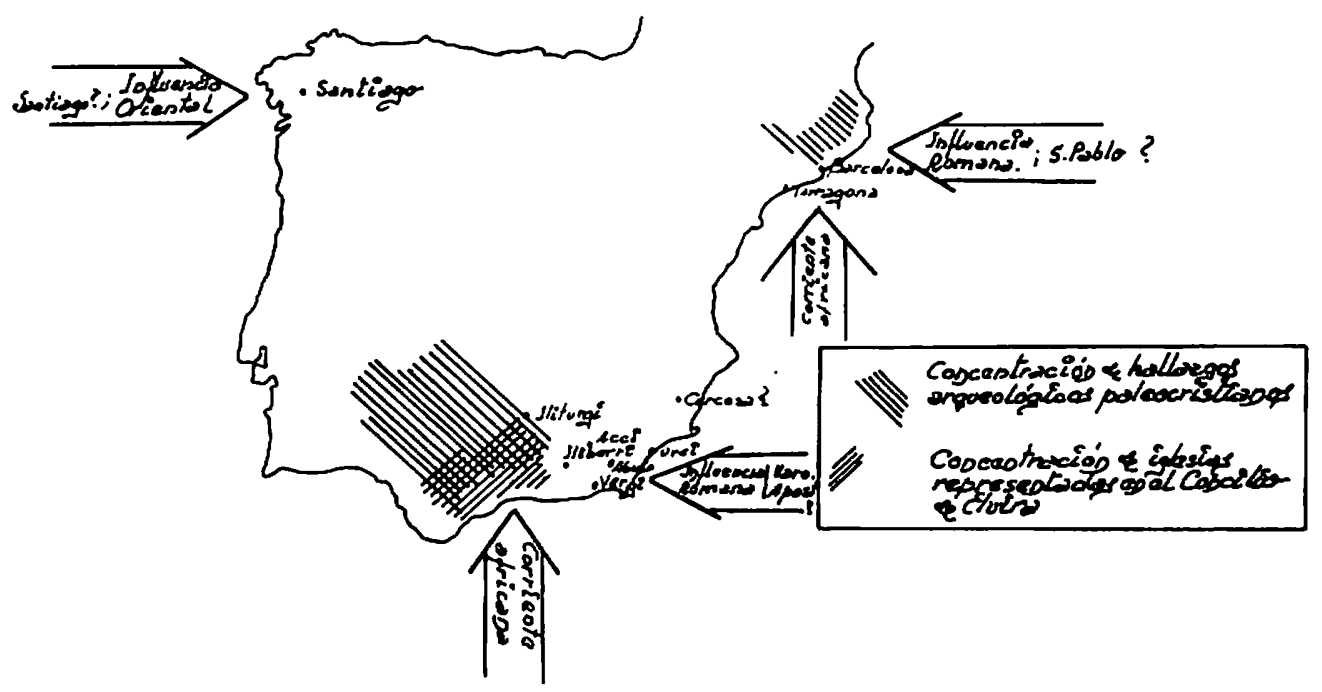

Mapa en que se representan las mayores concentraciones de sitios arqueológicos (Necrópolis romanas tardías y cristianas. Según Palol) y la de las iglesias representadas en el Concilio de Elvira, así como también las siete supuestas sedes de los Varones Apostólicos. Se debe hacer notar cómo el área de estos últimos no se corresponde con los mayores índices de cristianización que expresan las concentraciones señaladas.

Figura también en este mapa, las influencias de origen apostólico debidas a la tradicional acción de Santiago y de sus discípulos y la de los Siete Varones, y por otro lado la probable venida de San Pablo. Se señalan también los posibles influjos en la cristianización peninsular de las corrientes africanas. 
hace constar, el arqueólogo en cuestión, la presencia de dos corrientes, una romana y otra africana (92), muestra de un tráfico comercial con estos países.

Veamos lo que en lo referente al aspecto arqueológico del problema dice Blázquez (93). Comienza indicándonos cómo el material más antiguo paleocristiano es de finales del s. III, para pasar después a considerar el influjo africano sobre el cristianismo hispano, puesto de manifiesto en los hallazgos arqueológicos, sobre todo en las plantas basilicales y los mosaicos hallados en éstas. Hace constar, cómo la distribución del material arqueológico se concentra en la costa o en las grandes vías fluviales, caso respectivamente del norte de la Tarraconense y de la Bética, (cosa que destaca en el mapa de Palol ya comentado). Termina resumiendo, a la vista de lo que arqueología manifiesta, dado que la abundancia de estos materiales "con prototipos en el norte de Africa es tan grande que parece confirmar que las fuentes del cristianismo hispano son africanas" (94).

De esto último podemos deducir que la arqueología confirma lo que las fuentes escritas señalaron, esto es, el muy probable origen africano del cristianismo hispano, origen que la tradición de los Varones Apostólicos pretenderá rechazar haciéndole procedente de Roma. A este respecto Díaz y Díaz, hace constar cómo la posterior cristiandad española no quiere prescindir de sus orígenes apostólicos, teniendo interés en "presentar una Iglesia cuyos remotos orígenes empalman inmediatamente con los apóstoles" (95), cosa que queda manifiesta en la tradición de los Siete Varones, ya que éstos, como hemos visto, por un lado son ordenados en Roma por San Pedro y San Pablo y por otro se les llega a considerar discípulos de Santiago. Tradición ésta, que el último historiador mencionado considera como leyenda elaborada por un mozárabe

(92) Ibídem. p. 11.

(93) BLAZQUEZ. p. 188-89.

(94) Ibídem. p. 189.

(95) DIAZ Y DIAZ, M. C.-En torno a los orígenes del cristianismo bispánico, en Las Raices de España. Madrid, 1967. p. 423. 
en los finales del s. VIII, tal vez debida a "una especie de antídoto a la creciente difusión y popularidad de la tradición santiaguista" (96).

Pasemos a tratar ahora de una manera específica de esta tradición de los Siete Varones Apostólicos, empezando por los documentos a través de los cuales nos ha llegado, y de algunos de los cuales ya hemos hecho mención en otra parte de este trabajo, así como también de sus orígenes, según la opinión de distintos historiadores.

Según García Villada (97) son cinco las fuentes escritas, sobre los Varones: Martirologio histórico de Lyon; la Vida compendiada por el Cerratense; Vida de un códice complutense; Misa, Oficio y un Himno de la liturgia mozárabe; la relación que lleva por título "De missa apostolicae in Hispaniam docta, Iulianus et Felix". Este historiador considera que la noticia más antigua sobre los Siete Varones se remonta al s. V o VI (98).

Para el P. Llorca (99), los fundamentos de esta tradición se encuentran en los Calendarios Mozárabes, cuya redacción, según las investigaciones de los PP. Ferotín y Savio, es anterior al s. VI. Añade que el culto que a los Varones se tributa en Hispania empieza al mismo tiempo que la tradición.

En cuanto a la personalidad de los Siete Varones, el P. Flórez les supuso mártires (100). García Villada, a la vista de las fuentes por él manejadas deja la cuestión en suspenso (101). Vives, en cambio, cargado de argumentos, afirma que "los Varones Apostólicos fueron confesores en la acepción moderna de esta palabra, no mártires" (102). Nosotros, uniéndonos a la opinión de Vives, llegamos a la consecuencia de que al no

(96) Ibídem. p. 433.

(97) GARCIA VILLALDA. p. 151.

(98) Ibidem. p. 151.

(99) LLORCA. pp. 139 sgts.

(100) FLOREZ, p. 41.

(101) GARCIA VILLADA. p. 167.

(102) VIVES. Tradición y leyenda... p. 500. 
ser considerados como mártires, todo a cuanto a su muerte violenta se refiera debe ser considerado como leyenda. Si las fuentes dicen "descansaron en paz", quiere decir que su muerte fue natural, por tanto en fechas totalmente diferentes, incluso de años. El agrupamiento de los Siete Varones en una misma fiesta (103) se debe referir tan sólo al papel que representan como unidad en la evangelización peninsular.

Todo lo anterior y cuanto hasta ahora llevamos dicho respecto a esta tradición, muestra cómo su historicidad se hace muy sospechosa, pero ella ha sido estudiada y llevarla a conclusiones notables por José Vives, quien en un primer estudio (104) analiza las fuentes a través de las cuales nos ha llegado la relación de los hechos de los Varones Apostólicos, documentos que quedan perfectamente datados por este historiador a través de su trabajo.

Veamos primero la cronología que señala :

- S. X. Pasionario de Cardeña, manuscrito del British Musseum número 15.600 , fol. 179-81.

- S. X. Vitae Sanctorum, manuscrito 822 de la Biblioteca Nacional de Madrid.

- S. XI. Pasionario Silense, en la Biblioteca Nacional de París, manuscrito Nov. Acq. lat. 2171.

- S. XI. Manuscrito 494 de la Biblioteca Nacional de Madrid.

- SS. XI-XII. Códice Smaragdino, copia debida al P. Buriel en el manuscrito 13017 de la Biblioteca Nacional de Madrid.

(103) Esta fiesta está señalada, en la liturgia de hoy, el 21 de mayo. Sin embargo, en las primeras fuentes se la fijaba el día primero de este mes, pero ya en el Martirologio de Lyon figura el día 15, siguiéndole después Floro, el Parvo Romano y Adón, cuyos martirologios están enlazados entre sí. (GARCIA VILLADA. p. 167).

(104) VIVES. La "vita Torquati... pp. 223 a 30. 
Como vemos, se considera como más antiguo el Pasionario de Cardeña del s. X, el cual Vives en su trabajo le publica íntegro en su versión original latina, como Apéndice, a fin que pueda ser examinado por el investigador. Siendo ésta la fuente más antigua en la que se menciona a los Varones Apostólicos, este historiador se opone a García Villada, quien remonta las fuentes originales a los siglos V o VI. Deberemos resaltar, que aun en el supuesto de ser las fuentes más antiguas del $\mathrm{s}$. V, éstas refieren unos hechos acaecidos en el s. I., esto es, cuatrocientos años después.

Posteriormente al trabajo de Vives que mencionamos, sus tesis fueron impugnadas por el P. Vega en un largo artículo (105) en el cual defiende las opiniones del P. Flórez y de García Villada, en defensa de la historicidad de los Varones Apostólicos. Este último trabajo dio lugar a la importante respuesta de Vives (106) que, de ahora en adelante, será fundamental tener en cuenta siempre que se hable de los Varones Apostólicos.

Comienza Vives su trabajo haciendo un análisis de los textos considerados fundamentales por el $\mathrm{P}$. Vega, haciendo constar que uno de ellos, "El Pasionario Complutense" o "Vita Extensa", que figura en un manuscrito del s. XIII, ofrece el mismo texto que el Pasionario de Cardeña del s. $\mathrm{X}$, aduciendo nuevas razones para considerarle la más antigua referencia a los Varones Apostólicos que nos ha llegado "y que de él se derivan todos y sin excepción los demás textos antiguos" (107). Un poco más adelante añade una esencial afirmación: "todas las elucubraciones de los apologistas de la historicidad de los Varones Apostólicos parten del falso supuesto, tenido por un axioma, de que hubo una Passio, o narración, anterior (al manuscrito de Cardeña), más breve y por eso más antigua”.

Se extiende después Vives en una amplia demostración en cuanto a la consideración de documentos anteriores al de Cardeña, que hubieran sido

(105) VEGA, A. C. La venida de San Pablo a España y los Varones Apostólicos. En B.R.A.H. n..$^{154 .}$ Madrid, 1964, pp. 25 a 78.

(106) VIVES. Tradición y leyenda... pp. 495 a 508.

(107) Ibídem. p. 197. 
vertidos en otras fuentes. Más adelante pasa a precisar como "los Varones Apostólicos fueron confesores en la acepción moderna de la palabra, no mártires", según antes hemos señalado, basándose en un detenido estudio del texto del Pasionario (108). Añade, como consecuencia de lo anterior, que si fallecieron de muerte natural, según indica el Pasionario, - cada uno de ellos lo sería en distinta fecha, así es que no se explica como no se precisaron estas para señalar el día en que debía celebrarse su memoria, según la costumbre general de los cristianos. "La institución de una sola fiesta para los Siete Varones Apostólicos sólo pudo tener lugar como consecuencia de una Vita o leyenda que los glorificara" (109), por tanto todos los documentos litúrgicos que señalan esta fiesta pueden considerarse dependientes de dicha Vita y por tanto posteriores a ella.

Viene ahora el buscar en qué época pudo ser redactada esta Vita, "de la que conocemos una recensión segura del s. X" (110). El que referente a esta relación no se encuentra ningún antecedente en época visigoda, lleva a afirmar a Vives que se trata de una tradición que nace después de la invasión islámica. Confirma esta conclusión el estudio de los documentos de que dispone (111) y que tras su examen se llega a una conclusión

(108) Ibídem. p. 500-501.

(109) Ibídem. p. 501.

(110) Ibídem. p. 501.

(111) Exponemos a continuación el resumen del estudio sobre los documentos realizado por VIVES (Tradición... pp. 502 y 503):

- Oracionales. Si comparamos dos recensiones, una, del s. IX, en un manuscrito de Silos (hoy en el Britsh Musseum), en el que aparecen "formularios especiales para el oficio y misa de los Varones Apostólicos", la cual, "en sus nueve décimas partes reproduce exactamente los textos" de la otra, conocida como el Oracional Tarraconense, manuscrito de los ss. VII-VIII (hoy en Verona) en la que falta toda referencia a los Varones, tendremos la prueba de que en estas fechas (ss. VII-VIII), esta tradición es desconocida.

- Martirologios. Al estudiarles, nos encontramos con algo semejante a lo antes visto en los Oracionales. Así, en el mas antiguo, el Jerominiano de los ss. VI-VII, no figuran los Siete Varones, así como tampoco en el original de Beda, de la mitad del s. VIII, y el cual sirve de modelo al de Lyon, de principios del s. IX, al que siguen los de Floro, Adon y Usuardo, en todos los cuales se conmemora, en cambio, la fiesta de San Torcuato y sus compañeros.

- Calendarios. Examinados estos, en el único auténticamente visigodo, el de Carmona -el cual es precisamente de la Bética, y que da particularmente noticias de los santos de esta región- en su parte conocida, que es precisamente de los meses de Enero a Junio (la fiesta de los Varones es en Mayo) entre los cuales debería aparecer la conmemoración de los Siete Apostólicos, no se encuentra la menor referencia a ellos. En cambio, en todas las recensiones de los ss. X-XI, figura esta festividad. 
bien clara: solamente a partir del s. IX se encuentran menciones referentes a los Varones Apostólicos, lo cual lleva a confirmar la hipótesis de que esta tradición comienza después de la invasión musulmana.

Por último y tratando de fuentes documentales "se ha querido aducir en favor de la historicidad de los Varones Apostólicos el testimonio de las listas de obispos de Eliberri, Sevilla y Toledo del Códice Emilianense (s. X) de El Escorial" (112). Suponiendo correctas estas listas, se ha de hacer notar como la de Eliberri está encabezada por Cecilio, al que siguen ocho obispos para llegar a Fabiano, el Flaviano que asiste al Concilio de Elvira del 300-306 ?, y que figura en octavo lugar en un total de 19 prelados, (113), debiendo por tanto ser de los más ancianos. A este Cecilio, se le ha querido identificar con el compañero de Torcuato, que fundó la sede de Elvira. Creemos, según el análisis que a continuación vamos a hacer, que ello no es correcto.

Si consideramos a Flaviano como el décimo obispo de Elvira y se estima, una media de diez años, el tiempo de permanencia de los obispos en la sede, concluiremos que la fecha en que Cecilio, primer obispo, la regentaría estaría por los años 200 a 210 . Pero si elevamos al doble el tiempo de permanencia, o sea a veinte años, entonces pasaría a los años 100 a 120 en los que estuvo al frente del obispado de Iliberri. Dado el contexto histórico general de la difusión del cristianismo, nos inclinamos por la primera fecha como establecimiento del obispado de Iliberri, que bien pudiera ser de las primeras sedes fundadas en Hispania, aun cuando no precisamente por un discípulo de los Apóstoles, pero cuyo nombre, Cecilio, conocido por el autor de la tradición, le serviría para incluirle dentro de los Siete Apostólicos y precisamente en la sede que fundó. Como vemos, en cuanto a la segunda fecha dada como fundación de la diócesis de Elvira, entre los años 100 al 120, también es difícilmente aceptable, pues si los Varones Apostólicos fueron enviados a Hispania por los Após-

(112) VIVES. Tradición y leyenda... p. 504.

(113) VIVES, J. Concilios visigóticos e bispano-romanos. Barcelona-Madrid, 1963. p. 1. 
toles Pedro y Pablo y éstos fueron martirizados entre los años 64 y 67, muy jóvenes tendrían que ser sus Siete discípulos, al ser ordenados obispos, y mucho tiempo tardaron en establecer sus sedes. Para finalizar, y como antes hemos dicho, siguiendo la tesis de Vives (114), es perfectamente aceptable la verdadera existencia de este primer obispo eliberritano, Cecilio, cuyo nombre fue utilizado por el autor de la leyenda de los Varones Apostólicos.

Siguiendo también a Vives, hay un detalle que nos hace resaltar cuando se trata de la diócesis de Acci: es "el silencio en la memorable inscripción encontrada... clatada del año 652 que conmemora la dedicación de una basílica en Acci con la cleposición de unas treinta reliquias del Señor, de la Virgen, de santos hispanos, de las Galias, orientales, mártires y confesores, pero sin mención alguna de Torcuato, el supuesto fundador de la iglesia accitana" (115). Esto indica, de una manera precisa, el total desconocimiento del supuesto santo, Torcuato, en esta fecha, ya que si su existencia hubiera sido cierta, y aun cuando hubiese fallecido de muerte natural, su categoría de confesor permanecería, y lo lógico es que hubiese sido enterrado en la primera iglesia cle la diócesis por él fundada, de lo que habría quedado constancia debida, y en tal forma que sus reliquias, o alguna de ellas, hubiesen ido a formar parte de las veneradas en la basílica levantada en aquella ciudad por el año 652 .

Por otra parte, Vives añade que "este silencio de las inscripciones visigodas quizás deberíamos extenderlo a las del período mozárabe ss. IXXII) (116). Es extraño, continúa que dada la gran popularidad de la leyenda de los Varones Apostólicos por todo el norte de Hispania y las Galias "no se vean en las copiosas listas de reliquias de esta época y de estas regiones menciones de los santos de Acci". Este silencio de las fuentes mozárabes, respecto a los Siete Varones, parece confirmar la tesis de Vives de que esta "relación sólo pudo escribirse en el norte de la Penín-

(114) VIVES. Tradición y... p. 505.

(115) Ibídem. p. 504.

(116) Ibídem. p. 504. 
sula en una comunidad separada de la Bética por el infranqueable muro de la dominación musulmana" (117).

Todas estas consideraciones, llevan a la conclusión de cual fue la razón de que todos los cronistas de la época destacasen el hallazgo y traslado de las reliquias de San Indalecio, pues eran las únicas palpables de los Siete Varones y por tanto las que daban fe de su existencia.

Vives por último hace constar que cree "firmemente que existieron unos verdaderos varones apostólicos en España de nombre desconocido y que simbólicamente podían ser personificados en unos nombres elegidos entre los de la antigüedad" (118).

Antes de terminar de comentar los trabajos de este historiador hemos de hacer constar como su opinión ha sido aprobada por la mayor autoridad en hagiografía, el P. B. de Geifhier de los Bollandistas de Bruselas (119).

Después de todo cuanto acabamos de exponer referente a los Varones Apostólicos podemos concluir:

- La tradición de los Varones Apostólicos está basada en una leyenda que, todo lo más, se puede remontar al s. IX o finales del s. VIII. y que nació en el norte de la Península.

-El que unos hechos sucedidos en el siglo I pasen a ser relatados siete siglos después, sin que haya un nexo de unión en el tiempo, les convierte en pura leyenda, sin el menor rigor histórico.

- La total carencia de documentos epigráficos referentes a enterramientos o reliquias de los Siete Varones, aumenta las dudas sobre la realidad

(117) Ibídem. p. 506.

(118) Ibídem. p. 505.

(119) VIVES, J. Comunicación particular. 
de su existencia, ya que debemos descartar como tales las supuestas de Sant Indalectius episcopus urcitanus, según en su lugar hemos señalado.

-Así pues, podemos afirmar que carece de todo rigor histórico todo cuanto se refiere a los Siete Varones Apostólicos, primeros evangelizadores de Hispania, que, tal vez, su finalidad fue la de ligar la iglesia hispana a la romana, separándola de sus orígenes africanos.

\section{CONCLUSIONES}

Acabamos de ver como Vives demuestra, con sólidos argumentos, como la tradición de los Varones Apostólicos no es más que una leyenda. Ello nos lleva de nuevo a reconsiderar cuanto expusimos al tratar de San Indalecio, primer obispo de Urci.

En primer lugar, consecuencia cle cuanto antes se ha dicho, cabe hacerse una pregunta: ¿Quién fue Indalecio, el que hasta ahora ha sido considerado primer obispo urcitano y cuyas reliquias fueron trasladadas a San Juan de la Peña?

En principio, hemos tratado de mostrar, a través de un detenido estudio analítico del texto del monje Ebretmo, según la versión que de él da el P. Florez, de como, una parte muy importante, cae dentro de las tradiciones legendarias al gusto medieval, y como consideramos falso el pasaje de la lectura de la inscripción en que Indalecio aparece como primer obispo de Urci. También hemos señalado la posibilidad de que el templo en que se guardaban las reliquias del Santo fuera un primitivo martyrium dedicado a un mártir de nombre Indalecio.

Veamos ahora como podemos contestar la pregunta que más arriba hemos propuesto: Considerando cierta la existencia de las reliquias de San Indalecio, hoy veneradas en Jaca, y cierto también su traslado desde 
Pachina a San Juan de la Peña, hechos que no se pueden discutir; y siendo una leyenda, nada más, la tradición de los Siete Varones Apostólicos, las reliquias trasladadas no pudieron ser las de uno de ellos, pues su existencia es mera imaginación; por tanto debemos concluir que los huesos trasladados pertenecieron a los de un santo, mártir, de nombre Indalecio y que como tal recibían culto en Pechina.

Hagamos a continuación una relación ordenada cronológicamente de nuestra hipótesis:

-En Pechina, la Bayyana islámica, cuyo toponimo puede derivarse del hispano-romano Balena (120), durante las persecuciones decretadas por Roma hubo un mártir de nombre Indalecio.

-En su honor, y por la familia propietaria de una villa, los Ballienus, le fue levantado un martyrium, en el que sus reliquias recibieron culto, y en donde, tal vez, fueran enterrados los miembros de aquella familia, al igual de lo que se supone sucedió en el martyrium de La Alberca (Murcia) (121).

-Con la invasión islámica, los mozárabes continuaron rindiendo culto a estas reliquias en el antiguo martyrium, tal vez ampliado y convertido en iglesia o ermita.

\footnotetext{
(120) El nombre árabe de Bayyana, podemos hacerle derivar de uno hispano-romano, Bellena, que por sucesivas transformaciones da Bellana y Bayana. Este nombre latino Bellena puede considerarse un derivado adjetival con el sufijo ena, frente al cual podría haber un nombre de poseedor en enus o enios, lo que nos conduciría al gentilicio Ballienus (MENENDEZ PIDAL, R. Toponimia prerromana bispana. Madrid, 1952. p. 114-15). Dando este supuesto, por cierto, los Ballienus pudieron ser los propietarios de una gran villa que sería conocida por Ballena o Bellana. Hemos de destacar en este caso, la semejanza de este nombre con el árabe Baläna, antecedente de Villena. Esto supone la existencia del gentilicio Ballienus en dos puntos del sureste español. La transformación al pasar al árabe de un mismo nombre latino en dos versiones, es perfectamente admisible por la diferencia fonética del lenguaje hablado en ambos lugares, en que la doble ele unos la transforman en lam y los otros en doble yim. Como vemos, en el momento de la castellanización del topónimo árabe, se producen dos sonidos tan diferentes como los de Pechina-Paschana en un principio, y Villena.

(121) MERGELINA, C. El sepulcro de La Alberca (pp. 283 a 291) y SCHLUNK, H. $E l$ arte de la época paleocristiana en el sudeste español. La sinagoga de Elcbe y el martyrium de La Alberca (pp. 335 a 379), en Crónica del III Congreso Arqueológico del Sureste español. Murcia, 1947.
} 
-Al aparecer en el norte de la Península, y después extenderse por las Galias, la tradición de los Siete Varones Apostólicos, sus nombres gozaron de gran popularidad, siendo conocidos en todos los cenobios y por las jerarquías de la iglesia.

-Desde Murcia, y tal vez también desde Almería, debió ser relativamente frecuente la peregrinación a Santiago, de los mozárabes de la región, los cuales seguirían la ruta hacia el norte por Zaragoza para alcanzar San Juan de la Peña y desde aquí seguir el camino jacobeo. Este es, el que parece siguió el murciano Don Garcia, cuyo viaje tuvo por consecuencia el traslado de las reliquias del Santo de Pechina.

-En el s. XI hay una proliferación del culto a las reliquias, sobre todo en los monasterios, haciendo que la busca de éstas y su traslado a nuevos lugares, para su veneración, sea corriente. De ello tenemos una muestra de como desde San Ginés de la Jara (Cartagena) es trasladada a Francia las reliquias del santo de este nombre en 1023-24. (122).

-Debió suceder, que algunos de los mozárabes, que pasaron por San Juan de la Peña, comentasen el culto que había en Pechina a San Indaleció, cuyas reliquias allí se conservaban. Este nombre, de inmediato, fue identificado por los monjes con el del Varón Apostólico, lo que hizo que todo el monasterio se interesase por estas reliquias.

- Al pasar por San Juan de la Peña el caballero D. Garcia, jefe de una hueste cristiana en Murcia al servicio del islam, le fue encargada la recuperación de tales reliquias para ser trasladadas a aquel monasterio, a cuyo fin regresó a su tierra acompañado de dos monjes.

-Con motivo de una expedición a Almería, los monjes consiguen hacerse con las mencionadas reliquias, siendo llevadas a Murcia.

(122) TORRES FONTES, J. El monasterio de San Ginés de la Jara en la Edad Media. Murgetana, Vol. XXV. Murcia, 1965. p. 44

58 
- Bien el autor de las actas del traslado, el supuesto monje Ebretmo, o los dos que fueron a su busca, cuidaron de manifestar claramente que se trataban de las de San Indalecio, Obispo de Urci, al describir con todo detalle la inscripción que figuraba en su enterramiento.

- Posteriormente, al darse como ciertas, sin lugar a dudas, tanto la tradición de los Siete Varones, como la relación de Ebretmo, se identifica el lugar del hallazgo con Urci. Así, Pechina figuró como el solar de aquella ciudad, en cuantos durante la Edad Media trataron del tema, tanto en los redactores de la Crónica de San Juan de la Peña, como en el Tudense o Alfonso el Sabio.

-En los ss. XVI y XVII, la mayoría de los que escribieron sobre Urci la consideraron como antecesora de Almería, fijándola en Pechina siguiendo las fuentes más antiguas, la relación de Ebretmo.

- Los eruditos de los ss. XVIII y XIX, en su mayor parte, siguen identificando a Urci con Pechina, apoyándose siempre en fuentes anteriores, pero es que además buscan una confirmación en los autores clásicos que mencionan la ciudad hispana, acudiendo especialmente al Itinerario de Antonino.

-Ya en el siglo actual, siguiendo la tradición, la mayoría de los historiadores que tratan de pasada, tanto a Urci como a la Bayyana islámica, hacen a ésta sucesora de la primera.

-Así, como final, haremos constar de como una leyenda, convertida en hecho histórico, la de los Siete Varones Apostólicos, y de como una relación medieval, con todos los caracteres de apócrifa, las actas de Ebretmo. han servido para crear una afirmación histórica, la identificación del solar de Pechina con el lugar en que estuvo asentada la primitiva Urci. 
Por último, terminaremos haciendo unas consideraciones sobre la figura de San Indalecio, no precisamente el supuesto obispo, sino el mártir que recibió culto en Pechina.

Su nombre, según antes vimos, al parecer ibérico (el único no romano, considerado por García Villada), nos lleva a pensar que nos encontramos ante un santo mártir local, enraizado en las duras tierras de Almería, que debió gozar de un extendido culto en la cuenca del Andarax, que contaría con una verídica historia - tal vez fuera el primer mártir de origen local-, y la cual, lamentablemente no ha llegado hasta nosotros, al quedar enmascarada por el mito de una leyenda que suplantó su personalidad.

Se produce así un caso semejante al de San Ginés de Arles, cuyo culto a sus reliquias en San Ginés de la Jara ha sido estudiado por Torres Fontes, pues dicho historiador habla de una leyenda surgida no antes del s. XIV, en la cual el santo de la Jara es identificado con uno que vive y muere en estos parajes (123). En este caso, al contrario de lo sucedido en Pechina, la leyenda sustituye con un santo local al foráneo.

En Bayyana, se dió el caso, de que la figura de un supuesto obispo urcitano, discípulo de los apóstoles Pedro y Pablo que la misma leyenda no se atrevió a afirmar fuera mártir, envolviera y anulara la personalidad de un verdadero santo, hijo de las tierras almerienses. El robo de sus reliquias - dura es la frase pero creemos se acerca a la realidad- la islamización de los habitantes del Andarax, la despoblación de la ciudad marinera debida al progreso de Almería y la emigración a tierras cristianas de los mozárabes, trajo como consecuencia que la memoria del que fue santo patrono de aquellas tierras, Indalecio, fuera olvidada.

Tras la reconquista de Almería vuelve a aparecer el nombre de San Indalecio, pero no como el mártir de estas tierras, sino como el obispo urcitano. Esto trajo la consecuencia inmediata de la identificación de Urci

(123) Ibídem. p. 41. 
con Bayyana, lo cual le dió a Almería unos antecedentes que se remontaban a la primera cristianización de la Península, y más lejos aún al ser considerado Urci como uno de los primeros centros urbanos ibéricos. De esta forma Almería ganó una antigüiedad, parece cierto, fundada en falsedades, a cambio de perder un santo patrono, verdadero, hijo de sus tierras. 